\title{
HIGH-MG LAVAS FROM THE DARIGANGA VOLCANIC FIELD IN THE SOUTH-EASTERN MONGOLIA: PETROGENETIC MODEL OF MAGMATISM AT THE ASTHENOSPHERE-LITHOSPHERE BOUNDARY
}

\author{
I. S. Chuvashova ${ }^{1,2}$, S. V. Rasskazov ${ }^{1,2}$, T. A. Yasnygina ${ }^{1}$, E. A. Mikheeva ${ }^{1,2}$ \\ ${ }^{1}$ Institute of the Earth's Crust, Siberian Branch of RAS, Irkutsk, Russia \\ ${ }^{2}$ Irkutsk State University, Irkutsk, Russia
}

\begin{abstract}
It is revealed that high-Mg lavas $(\mathrm{MgO}=11.0-15.8$ wt. \%) are spatially controlled by linear zones extending for more than $90 \mathrm{~km}$ and demonstrate chemically distinct differences from moderately-Mg compositions (MgO=3.0-11.0 wt. \%), which occupy the isometric area of the Dariganga volcanic field. From the major and trace-element data on the rocks in the field under study, we have justified a petrogenetic mode of the uniform one-level mantle magmatism. Our model differs from the contrasting magmatism model of the processes that developed at two levels beneath the Hannuoba volcanic field. Based on tomography images showing the East Mongolian local low-velocity anomaly in the upper mantle, we suggest that magmatism of Type 1 occurred in the mantle sources at the asthenosphere-lithosphere boundary and the underlying asthenosphere as a reflection of a relatively weak mantle flow that may have ascended from a depth of $\sim 250 \mathrm{~km}$. Magmatism of Type 2 occurred in the isolated sources of the sub-lithospheric mantle and the asthenosphere-lithosphere boundary as an evidence on the initially strong mantle flow that may have ascended from a depth of $\sim 410 \mathrm{~km}$.
\end{abstract}

Key words: volcanism, Cenozoic, Asia, Mongolia, China, geodynamics, asthenosphere, lithosphere.

Recommended by D.P. Gladkochub 3 December 2012

Citation: Chuvashova I.S., Rasskazov S.V., Yasnygina T.A., Mikheeva E.A., 2012. High-Mg lavas from the Dariganga volcanic field in the South-Eastern Mongolia: petrogenetic model of magmatism at the asthenospherelithosphere boundary. Geodynamics \& Tectonophysics 3 (4), 385-407. doi:10.5800/GT-2012-3-4-0081.

\section{ВЫСОКОМАГНЕЗИАЛЬНЫЕ ЛАВЫ ДАРИГАНСКОГО ВУЛКАНИЧЕСКОГО ПОЛЯ, ЮГО-ВОСТОЧНАЯ МОНГОЛИЯ: ПЕТРОГЕНЕТИЧЕСКАЯ МОДЕЛЬ МАГМАТИЗМА НА АСТЕНОСФЕРНО-ЛИТОСФЕРНОЙ ГРАНИЦЕ}

\author{
И. С. Чувашова ${ }^{1,2}$, С. В. Рассказов ${ }^{1,2}$, Т. А. Ясныгина ${ }^{1}$, Е. А. Михеева ${ }^{1,2}$ \\ ${ }^{1}$ Институт земной коры СО РАН, Иркутск, Россия \\ ${ }^{2}$ Иркутский государственный университет, Иркутск, Россия
}

\begin{abstract}
Аннотация: Установлен пространственный контроль высокомагнезиальных вулканических пород (MgO=11.0-15.8 мас. \%) линейными зонами протяженностью более 90 км и резкие отличия их химического состава от умеренномагнезиальных (MgO=3.0-11.0 мас. \%) пород, занимающих всю изометричную территорию вулканического поля Дариганга. При сравнительном анализе петрогенных и малых элементов пород этого поля обоснована петрогенетическая модель мантийного магматизма одного глубинного уровня, в отличие от модели контрастных магматических процессов, проявленных на двух глубинных уровнях под вулканическим полем Ханнуоба. С учетом томографиче-
\end{abstract}


ских данных о наличии Восточно-Монгольской низкоскоростной аномалии в верхней мантии, предполагается, что магматизм первого типа получил развитие в источниках на границе астеносферы-литосферы и непосредственно нижележащей астеносферы как отражение относительно слабого мантийного потока, вероятно, поднимавшегося с глубины 250 км. Магматизм второго типа возник в обособленных источниках подлитосферной мантии и границы астеносферы-литосферы как свидетельство изначально сильного мантийного потока, возможно, зародившегося на глубине 410 км.

Ключевые слова: вулканизм, кайнозой, Азия, Монголия, Китай, геодинамика, астеносфера, литосфера.

\section{1. ВВЕДЕНИЕ}

В петрологических моделях глубинной магматической динамики важное значение имеет исследование соотношений петрогенных оксидов и малых элементов высокомагнезиальных и умеренномагнезиальных вулканических пород. Первые породы имеют повышенную ликвидусную температуру, вторые - пониженную. Происхождение расплавов с низкими содержаниями $\mathrm{MgO}$ часто объяснялось кристаллизационной дифференциацией высокомагнезиальных магм. Для получения первичной высокотемпературной мантийной выплавки рассчитывались модели отделения ликвидусного оливина. Между тем такие модели чаще всего не подтверждались наличием отделившихся минеральных фаз этого типа в вулканических породах территорий. Представление о том, что мантийные выплавки должны иметь высокомагнезиальный состав и перидотитовый источник, основанное на классических экспериментах Д.Х. Грина и А.Э. Рингвуда, сменилось работами, в которых допускалась множественность мантийных источников. Приводились экспериментальные доказательства происхождения магматических расплавов умеренномагнезиального состава при плавлении пироксенитов [Lloyd et al., 1985; Sobolev et al., 2005; Herzberg, 2011]. Модели глубинного магматизма требуют также дополнительной аргументации в свете конкретных пространственно-временных соотношений между извержениями высокомагнезиальных и умеренномагнезиальных лав.

В настоящей работе рассматриваются соотношения состава лав с высокими и умеренными концентрациями $\mathrm{MgO}$ вулканического поля Дариганга, исследуется характер пространственного распределения высокомагнезиальных лав и при сравнительном анализе данных по петрогенным и малым элементам вулканических пород полей Дариганга и Ханнуоба обосновывается петрогенетическая модель глубинного магматизма.

Аналитические исследования микроэлементного состава вулканических пород выполнены в лаборатории изотопии и геохронологии Института земной коры СО РАН (химик-аналитик М.Е. Маркова) методом
ICP-MS на масс-спектрометре Agilent 7500се в рамках работы Байкальского аналитического центра коллективного пользования. Характеристика использованных методик приведена в работе [Yasnygina et al., 2003]. Петрогенные элементы определены в аналитическом центре института классическим «мокрым» методом (аналитики Г.В. Бондарева и М.М. Самойленко).

\section{2. ОБЩАЯ ХАРАКТЕРИСТИКА ОБЪЕКТА ИССЛЕДОВАНИЙ}

Вулканическое поле расположено в Юго-Восточной Монголии в координатах $113-115^{\circ}$ в.д. и 44.5$45.0^{\circ}$ с.ш. на приграничной территории с Китаем [Vlodavets, 1955]. Продолжение вулканических проявлений на китайскую территорию имеет собственное название Абага [Zhou et al., 1988] или Даленуор [Liu et al., 2001]. Вулканическая полоса Абага-Дариганга шириной около 100 км протягивается в направлении северо-северозапад - юго-юго-восток на расстояние около 350 км.

На монгольской территории находится более 200 шлаковых и шлаколавовых построек. По их пространственному распределению поле Дариганга разделяется на две части: северо-западную, в которой постройки контролировались разломами северо-восточной ориентировки (азимут $45^{\circ}$ ), и юго-восточную, в которой постройки контролировались разломами восток-северовосточной ориентировки (азимут $70^{\circ}$ ) (рис. 1).

Лавы юго-восточной части поля перекрывают поднятие с расчлененным рельефом хр. Нукут-Дабан, протягивающегося в северо-северо-восточном направлении вдоль северного края Северо-Китайского кратона и Солонкерского шва закрывшегося позднепалеозойского палеоокеана [Şengör, Natal'in, 1996]. Лавы вулканов северо-западной части поля представляют собой аккумулятивное сооружение между Тамцагской и Онгонской впадинами, которые обозначают новейший предгорный прогиб, сопряженный с поднятием хр. Нукут-Дабан (рис. 2). Бурение территории не проводилось, и глубина залегания фундамента в рифтовых впадинах под покровом лав неясна.

Лавы Дариганского поля датируются интервалом миоцен-квартер. По имеющимся $\mathrm{K}-\mathrm{Ar}$-датировкам 


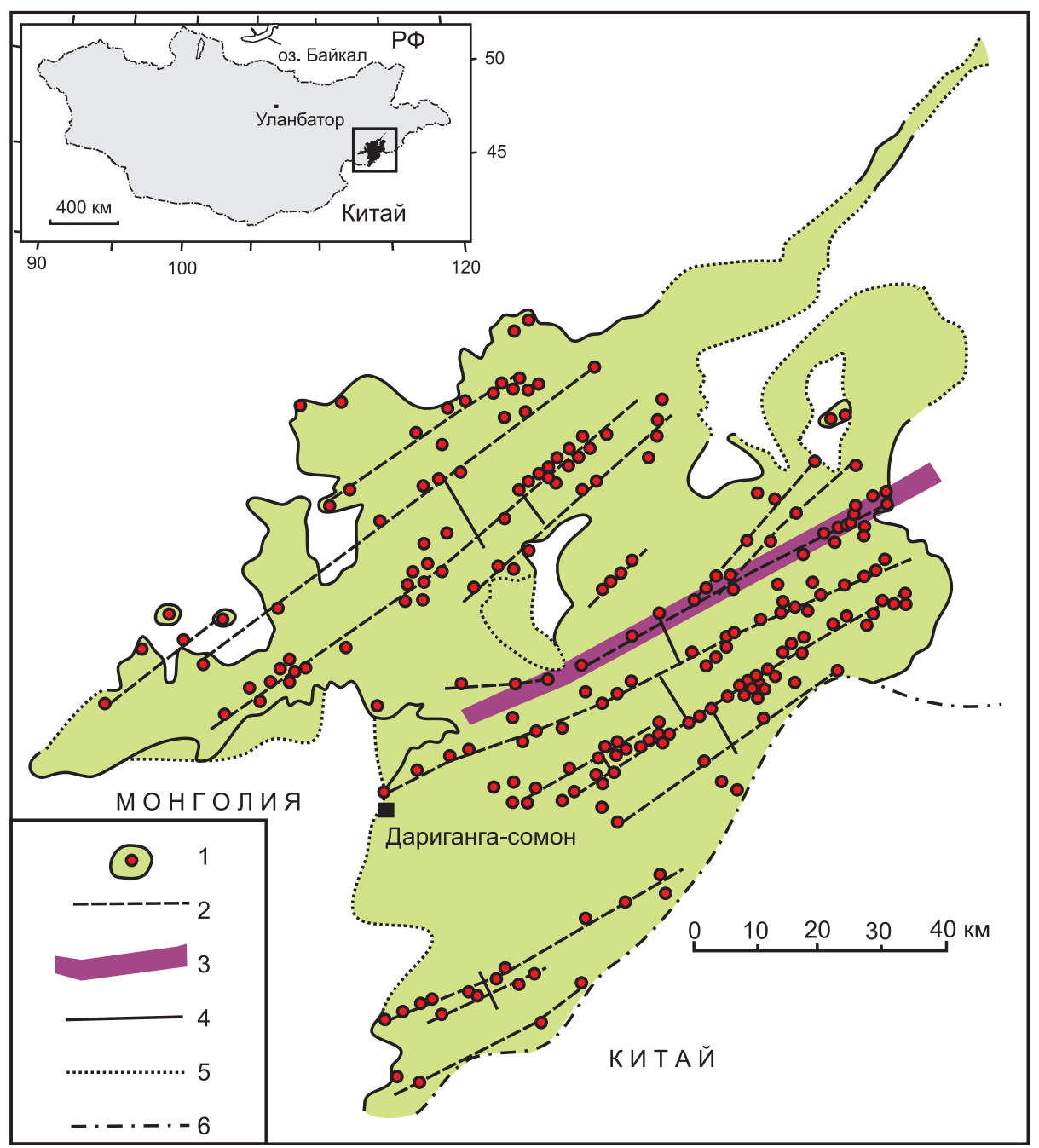

Рис. 1. Линейное распределение вулканических построек поля Дариганга. 1 - вулканы; 2 - предполагаемые разломы, соответствующие линиям вулканов; 3 - граница между территориями с разнонаправленными вулканическими линиями, ориентированными на северовосток (азимут $45^{\circ}$ ) и восток-северо-восток (азимут $70^{\circ}$ ); 4-5 - границы лавовых потоков и покровов: установленные (4) и предполагаемые (5); 6 - государственная граница. Схема приведена по работе [Vlodavets, 1955] с изменениями и дополнениями.

Fig. 1. Linear distribution of volcanic edifices of the Dariganga field. 1 - volcanoes; 2 - inferred faults that correspond to lines of volcanoes; 3 - the boundary between the areas with multidirectional volcanic lines oriented to the north-east (azimuth $45^{\circ}$ ) and the east-north-east (azimuth $70^{\circ}$ ); 4 - confirmed boundaries of lava flows and covers; 5 - assumed boundaries of lava flows and covers; 6 - the state border. The scheme has been modified after [Vlodavets, 1955].

[Kononova et al., 1988; Saltykovsky, Genshaft, 1985], на поле Дариганга отсутствуют вулканические породы древнее 18 млн лет. Лавы поля Абага (Даленуор) относятся к плиоцену и квартеру [Liu et al., 2001].

\section{3. СИСТЕМАТИКА ВУЛКАНИЧЕСКИХ ПОРОД: ПЕТРОХИМИЧЕСКИЕ ОТЛИЧИЯ \\ ВЫСОКОМАГНЕЗИАЛЬНЫХ И УМЕРЕННОМАГНЕЗИАЛЬНЫХ СОСТАВОВ}

B.В. Кепежинскас [Kepezhinskas, 1979] рассматривала вулканические породы Дариганского поля как типичную натровую серию Азии, исходя из распро- странения в щелочных базальтоидах анортоклазовых мегакристаллов. При детальном опробовании вулканических аппаратов и лавовых потоков, выполненном А.Я. Салтыковским и Ю.С. Геншафтом [Saltykovsky, Genshaft, 1985], получен массив данных с интервалом $\mathrm{SiO}_{2}$ от 39.9 мас. \% (обр. 517/79, поток в 5 км севернее влк. Думду-Нарт-Ула, юго-восточный борт урочища Удын-Бурун-Шире) до 51.38 мас. \% (обр. 5/76, поток влк. Асхатын-Дзун-Цаган-Толгой). Приведение суммы петрогенных оксидов к 100 мас. \% на классификационной диаграмме TAS (total alkalis - silica, без потерь при прокаливании) дает интервал содержаний $\mathrm{SiO}_{2}$ по массиву данных этих авторов от 40.75 до 52.03 мас. \%. Исследуя соотношения калия и натрия в вулканических породах Дариганги с применением распростра- 


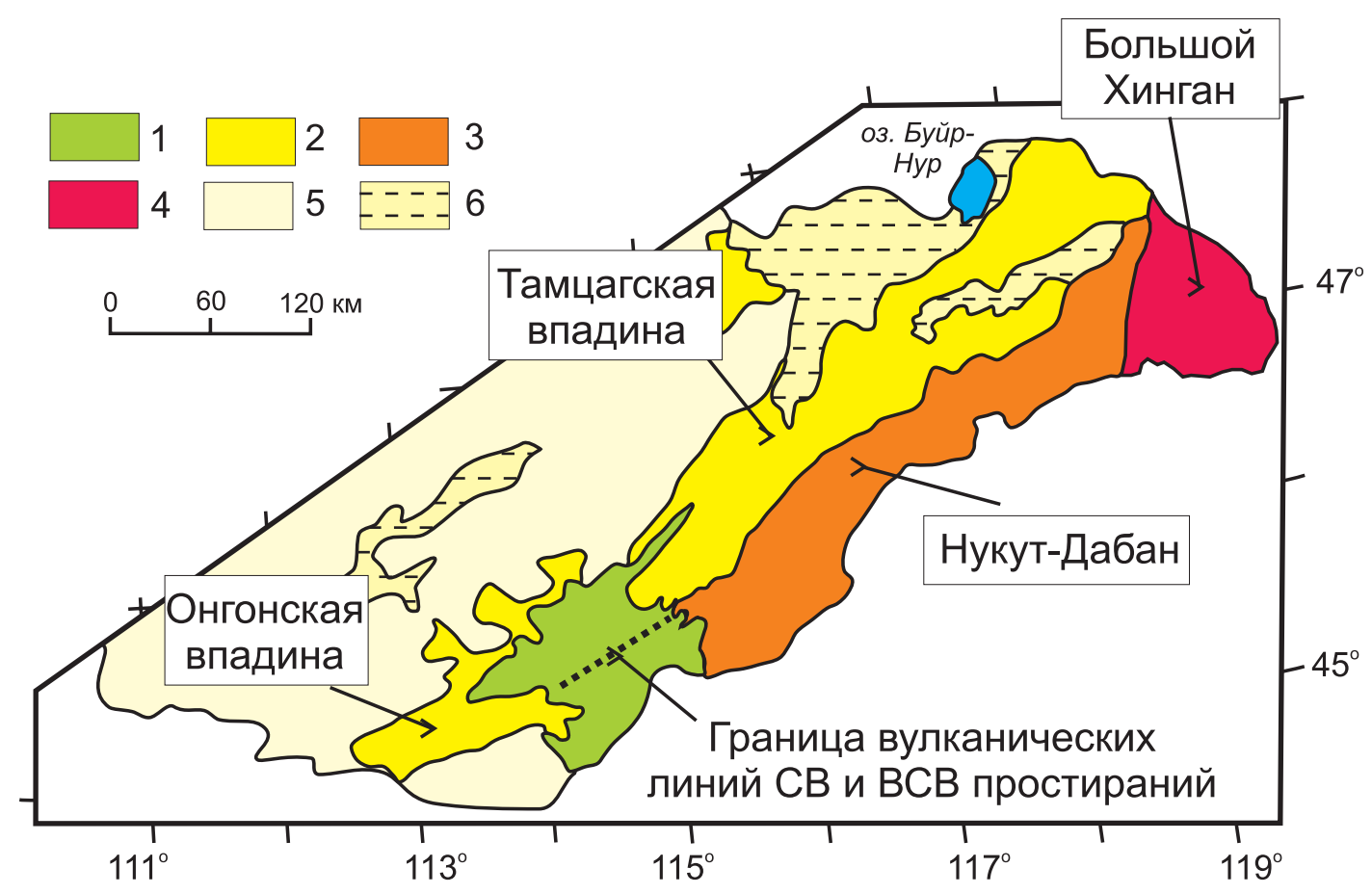

Рис. 2. Местоположение Дариганского вулканического поля в новейших структурах Юго-Восточной Монголии. 1 - Дариганское вулканическое поле; 2 - предгорный прогиб; 3-4 - поднятия северо-восточного (3) и субмеридионального (4) простирания; 5 - денудационная цокольная равнина; 6 - аккумулятивная равнина. Границы новейших структур приведены по работе [Syrnev, 1982]. Граница территорий с разнонаправленными вулканическими линиями поля Дариганга показана по рис. 1 как продолжение зоны перехода между поднятием хр. Нукут-Дабан и предгорным прогибом.

Fig. 2. Location of the Dariganga volcanic field in the recent structures of the South-Eastern Mongolia. 1 - Dariganga volcanic field; 2 - foredeep; 3-4 - uplifts of the northeast-southwest (3) and north-south (4) strikes; 5 - denudation pediment plain; 6 - depositional plain. Boundaries of recent structures are shown according to [Syrnev, 1982]. The boundary between areas with different directions of volcanic lines of the Dariganga field is shown in Figure 1 as a continuation of the transition zone between the Nukut Daban ridge and the adjacent foredeep.

ненных диаграмм, авторы пришли к выводу о несовершенстве «принципов выделения так называемых натриевых и калиевых серий щелочных пород по типам гавайских серий и ассоциаций щелочно-базальтовых пород островов Тристан-да-Кунья и Гоф... Мы полностью поддерживаем представления о принадлежности вулканических пород Дариганги к натриевой серии... Возможно, правильнее, придерживаясь современных рекомендаций, относить их к калинатровой серии пород умеренной щелочности» [Saltykovsky, Genshaft, 1985, p. 27].

В цитированной работе вулканические породы Дариганского поля отнесены к десяти петрохимическим типам: 1) кварцевым толеитам, 2) толеитам, 3) оливиновым базальтам, 4) щелочным оливиновым базальтам, 5) гавайитам, 6) муджиеритам, 7) нефелиновым базанитам, 8) нефелиновым гавайитам, 9) нефелиновым муджиеритам, 10) нефелиновым бенморитам. На вариационных диаграммах, включающих $\mathrm{SiO}_{2}$, сумму щелочей, $\mathrm{Na}_{2} \mathrm{O}, \mathrm{K}_{2} \mathrm{O}, \mathrm{TiO}_{2}$ и $\mathrm{Fe}_{2} \mathrm{O}_{3}$, показано сплошное распределение фигуративных точек без какого-либо группирования.

В нашей коллекции образцов вулканических пород поля Дариганга нижний предел измеренных содержа- ний $\mathrm{SiO}_{2}$ составляет 42.38 мас. \% (обр. $\mathrm{MN}-09-1570$, базальтовая линза в желтых туфах основания постройки Авгойт-Ула), верхний предел - 52.21мас. \% (обр. MN-09-1407, северная часть поля). Приведенные к $100 \%$ концентрации $\mathrm{SiO}_{2}$ на TAS-диаграмме (без потерь при прокаливании) равны, соответственно, 43.50 и 52.34 мас. \% (рис. 3). Расхождение в содержаниях $\mathrm{SiO}_{2}$ на нижнем пределе около 2.5 мас. \% может быть связано с систематической лабораторной ошибкой. Совместное нанесение петрохимических данных на вариационные диаграммы делает тренды расплывчатыми, поэтому в настоящей работе результаты петрохимических анализов, приведенные А.Я. Салтыковским и Ю.С. Геншафтом, используются только для общей ориентировки, а все графики приводятся по результатам новых аналитических определений.

На рис. 3 фигуративные точки умеренномагнезиальных лав (MgO=3.0-11.0 мас. \%) из выборки новых аналитических данных также имеют сплошное распространение в области базанита-тефрита, трахибазальта и базальта. Основная высокомагнезиальная группа лав (MgO=11-14 мас. \%) концентрируется в нижней части поля базанита и в левой части поля трахибазальта с общим интервалом $\mathrm{SiO}_{2} 43.9-47.2$ мас. \% 


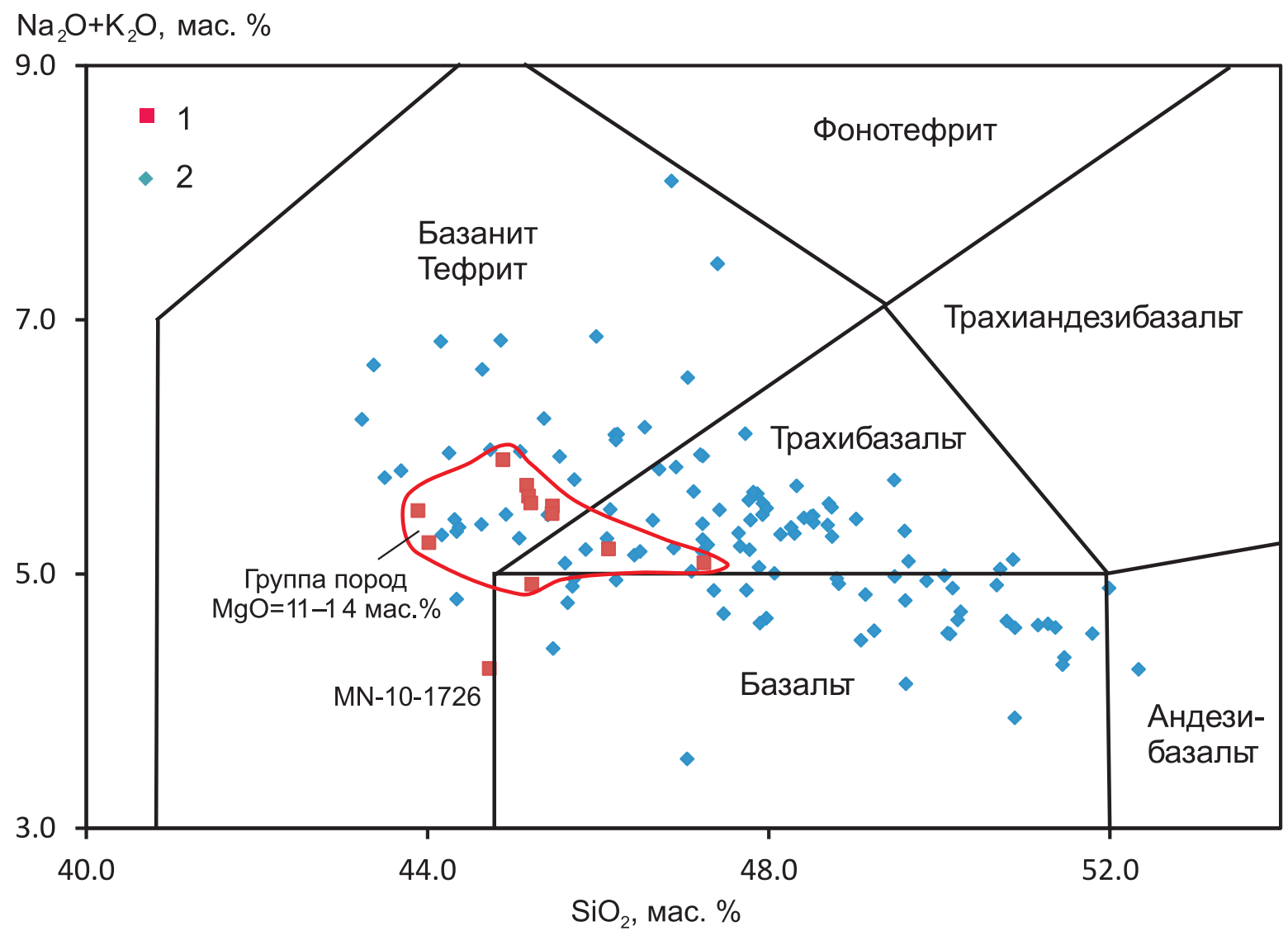

Рис. 3. Соотношения высокомагнезиальной и умеренномагнезиальной групп вулканических пород Дариганского поля на классификационной диаграмме TAS (total alkalis - silica) Международного союза геологических наук. 1-2 - высокомагнезиальные (1) и умеренномагнезиальные (2) вулканические породы. Базанит отличается от тефрита содержанием MgO более 10 мас. \%. Сумма петрогенных оксидов пересчитана на 100 мас. \% без потерь при прокаливании $\left(\mathrm{H}_{2} \mathrm{O}^{-}-\right.$просушка проб при $100{ }^{\circ} \mathrm{C}, \mathrm{H}_{2} \mathrm{O}^{+}-$отжиг при температуре $\left.900^{\circ} \mathrm{C}\right)$.

Fig. 3. The TAS diagram of the IGU for high- and moderate-Mg groups of volcanic rocks from the Dariganga field. 1 - high-Mg volcanic rocks; 2 - moderate-Mg volcanic rocks. A basanite differs from a tephrite by the $\mathrm{MgO}$ content exceeding $10 \mathrm{wt}$. \%. The total of major oxides is recalculated to 100 wt. \% on loss of ignition free basis $\left(\mathrm{H}_{2} \mathrm{O}^{-}-\right.$drying samples at $100{ }^{\circ} \mathrm{C} ; \mathrm{H}_{2} \mathrm{O}^{+}-$annealing at $\left.900{ }^{\circ} \mathrm{C}\right)$.

и $\mathrm{Na}_{2} \mathrm{O}+\mathrm{K}_{2} \mathrm{O}=4.9-5.9$ мас. \%. Состав наиболее высокомагнезиального базальта (обр. MN-10-1726, MgO= $=15.8$ мас. \%) отличается от этой группы пород низким содержанием суммы щелочей $\left(\mathrm{Na}_{2} \mathrm{O}+\mathrm{K}_{2} \mathrm{O}=4.3\right.$ мас. \%.). Рой фигуративных точек умеренномагнезиальных пород перекрывает основную группу высокомагнезиальных базанитов и трахибазальтов и распространяется в верхнюю и правую области диаграммы. Таким образом, с учетом концентраций MgO, на TAS-диаграмме выделяется общий тренд расходящегося веера: наиболее магнезиальный базальт (обр. MN-10-1726) $\rightarrow$ основная группа высокомагнезиальных пород $\rightarrow$ умеренномагнезиальные породы.

Наиболее магнезиальный базальт имеет самое низкое содержание $\mathrm{K}_{2} \mathrm{O}$ (0.8 мас. \%) (таблица). Основная группа высокомагнезиальных пород разделяется на две подгруппы с содержаниями этого оксида 1.1-1.3 и $1.8-2.3$ мас. \%. По значению $\mathrm{K}_{2} \mathrm{O} / \mathrm{Na}_{2} \mathrm{O}=0.24$ наиболее магнезиальный базальт относится к натровой серии. В менее калиевой подгруппе (обр. MN-10-1723 и MN-
09-1508) отношение этих оксидов увеличивается до интервала 0.27-0.38, а в более калиевой - до интервала 0.51-0.74 (рис. 4).

В группе умеренномагнезиальных пород отчетливо выделяется главный умереннокалиевый тренд, сопровождающийся боковыми второстепенными низкокалиевым и высококалиевым трендами, протягивающимися в области пониженных содержаний $\mathrm{SiO}_{2}$. Основная группа высокомагнезиальных пород занимает осевую часть главного тренда умеренномагнезиальных. Два менее калиевых высокомагнезиальных состава попадают на низкокалиевый тренд умеренномагнезиальной группы.

В координатах $\mathrm{FeO} / \mathrm{MnO}-\mathrm{MgO}$ общий тренд «наиболее магнезиальный базальт $\rightarrow$ основная группа высокомагнезиальных пород $\rightarrow$ умеренномагнезиальные породы» направлен вдоль направления выплавок, образующихся при снижении степени частичного плавления высокомагнезиального пироксенита (рис. 5). Относительное смещение роя точек от этого направления 
I.S. Chuvashova et al.: High-Mg lavas from the Dariganga volcanic field...

Химический состав высокомагнезиальных и двух ключевых образцов умеренномагнезиальных (MN-09-1570 и MN-09-1407) вулканических пород

Chemical compositions of high- and moderate-Mg volcanic rocks (two key samples of the latter, MN-09-1570 and MN-09-1407)

\begin{tabular}{|c|c|c|c|c|c|c|}
\hline № п/п & 1 & 2 & 3 & 4 & 5 & 6 \\
\hline № образца & MN-09-1416 & MN-09-1447 & MN-09-1505 & MN-09-1508 & MN-09-1573 & MN-09-1574 \\
\hline $\mathrm{SiO}_{2}$, мас. \% & 45.14 & 45.02 & 42.71 & 45.08 & 47.08 & 44.28 \\
\hline $\mathrm{TiO}_{2}$ & 2.68 & 2.74 & 3.57 & 3.33 & 2.57 & 3.10 \\
\hline $\mathrm{Al}_{2} \mathrm{O}_{3}$ & 11.87 & 12.05 & 11.99 & 11.40 & 12.00 & 11.49 \\
\hline $\mathrm{Fe}_{2} \mathrm{O}_{3}$ & 4.29 & 1.90 & 2.55 & 6.01 & 2.05 & 2.69 \\
\hline $\mathrm{FeO}$ & 8.11 & 10.32 & 9.78 & 6.75 & 9.63 & 9.81 \\
\hline $\mathrm{MnO}$ & 0.16 & 0.18 & 0.16 & 0.15 & 0.17 & 0.15 \\
\hline $\mathrm{MgO}$ & 11.88 & 11.49 & 11.16 & 11.19 & 12.16 & 11.32 \\
\hline $\mathrm{CaO}$ & 9.11 & 9.52 & 9.21 & 8.26 & 8.34 & 8.85 \\
\hline $\mathrm{Na}_{2} \mathrm{O}$ & 3.57 & 3.76 & 2.98 & 4.00 & 3.30 & 3.47 \\
\hline $\mathrm{K}_{2} \mathrm{O}$ & 1.90 & 1.92 & 2.11 & 1.08 & 1.77 & 2.03 \\
\hline $\mathrm{P}_{2} \mathrm{O}_{5}$ & 0.80 & 0.75 & 0.84 & 0.87 & 0.58 & 0.85 \\
\hline $\mathrm{H}_{2} \mathrm{O}^{-}$ & 0.11 & 0.05 & 0.36 & 0.22 & 0.10 & 0.37 \\
\hline $\mathrm{H}_{2} \mathrm{O}^{+}$ & 0.64 & 0.76 & 3.00 & 1.38 & 0.74 & 1.33 \\
\hline Сумма & 100.24 & 100.46 & 100.42 & 99.72 & 100.49 & 99.74 \\
\hline Sc, мкг/Г & 31.2 & 24.2 & 20.9 & 21.1 & 22.0 & 20.5 \\
\hline $\mathrm{V}$ & 253 & 258 & 269 & 240 & 245 & 219 \\
\hline $\mathrm{Cr}$ & 436 & 414 & 371 & 396 & 452 & 346 \\
\hline Co & 68 & 73 & 66 & 63 & 64 & 62 \\
\hline $\mathrm{Ni}$ & 435 & 349 & 358 & 425 & 457 & 287 \\
\hline $\mathrm{Rb}$ & 49.4 & 35.3 & 34.8 & 18.7 & 29.5 & 39.0 \\
\hline $\mathrm{Sr}$ & 1064 & 1135 & 1187 & 916 & 897 & 1055 \\
\hline $\mathrm{Y}$ & 35.6 & 36.5 & 30.8 & 31.6 & 30.5 & 31.9 \\
\hline $\mathrm{Zr}$ & 309 & 287 & 312 & 302 & 257 & 306 \\
\hline $\mathrm{Nb}$ & 82 & 82 & 86 & 77 & 73 & 80 \\
\hline Cs & 0.94 & 0.62 & 0.48 & 0.89 & 0.24 & 0.42 \\
\hline $\mathrm{Ba}$ & 798 & 610 & 722 & 579 & 544 & 717 \\
\hline $\mathrm{La}$ & 61 & 60 & 47 & 49 & 46 & 55 \\
\hline $\mathrm{Ce}$ & 117 & 118 & 96 & 100 & 91 & 110 \\
\hline $\mathrm{Pr}$ & 12.7 & 13.6 & 11.0 & 11.4 & 10.1 & 12.5 \\
\hline $\mathrm{Nd}$ & 52 & 54 & 47 & 48 & 42 & 52 \\
\hline $\mathrm{Sm}$ & 10.9 & 11.9 & 10.2 & 10.6 & 9.2 & 11.0 \\
\hline $\mathrm{Eu}$ & 3.3 & 3.7 & 3.2 & 3.2 & 2.8 & 3.4 \\
\hline $\mathrm{Gd}$ & 9.8 & 10.8 & 9.1 & 9.4 & 8.2 & 10.0 \\
\hline $\mathrm{Tb}$ & 1.3 & 1.4 & 1.2 & 1.3 & 1.2 & 1.4 \\
\hline Dy & 6.8 & 7.6 & 6.1 & 6.3 & 5.7 & 6.4 \\
\hline Ho & 1.1 & 1.2 & 1.0 & 1.1 & 1.0 & 1.2 \\
\hline Er & 2.7 & 2.9 & 2.4 & 2.5 & 2.3 & 2.6 \\
\hline $\mathrm{Yb}$ & 1.8 & 2.1 & 1.6 & 1.7 & 1.6 & 1.6 \\
\hline $\mathrm{Lu}$ & 0.24 & 0.25 & 0.19 & 0.19 & 0.19 & 0.26 \\
\hline $\mathrm{Hf}$ & 6.5 & 5.7 & 6.7 & 6.6 & 5.5 & 6.5 \\
\hline $\mathrm{Ta}$ & 4.2 & 4.0 & 4.8 & 4.3 & 3.8 & 4.5 \\
\hline $\mathrm{Pb}$ & 8.8 & 3.9 & 3.5 & 4.1 & 6.1 & 4.4 \\
\hline Th & 7.2 & 6.6 & 5.7 & 5.9 & 5.2 & 6.5 \\
\hline $\mathrm{U}$ & 1.62 & 1.66 & 1.65 & 1.55 & 0.81 & 1.63 \\
\hline
\end{tabular}

вниз может свидетельствовать о примеси в источнике иного материала, состав которого пока не ясен. Важно подчеркнуть, что петрогенетическая модель плавления перидотита в случае вулканических пород поля Дариганга не применима.

\section{4. СОВМЕСТИМЫЕ И НЕСОВМЕСТИМЫЕ ЭЛЕМЕНТЫ}

В наиболее магнезиальном базальте определены сравнительно высокие концентрации совместимых эле. ментов (Ni=589 мкг/г, Cr=739 мкг/г). В других образ- цах высокомагнезиальной группы с понижением содержания $\mathrm{MgO}$ концентрации $\mathrm{Ni}$ и $\mathrm{Cr}$ снижаются, соответственно, от 478 до 287 и от 460 до 346 мкг/г. Образцы этой группы с $\mathrm{MgO} \sim 11.3$ мас. \% характеризуются вариациями Ni от 287 до 425 и Cr от 346 до 445 мкг/г. При повышении MgO до 11.8-12.7 мас. \% содержания Ni повышаются до 391-478 мкг/г, а Cr - до интервала 411-460 мкг/г. Среди умеренномагнезиальных лав отдельные образцы обнаруживают высокие концентрации Ni (до 460 мкг/г) и $\mathrm{Cr}$ (до 660 мкг/г). На диаграмме $\mathrm{Cr}$ - MgO образцы высокомагнезиальных и умеренномагнезиальных базальтов образуют отдель- 
End of table

\begin{tabular}{|c|c|c|c|c|c|c|c|}
\hline № п/п & 7 & 8 & 9 & 10 & 11 & 12 & 13 \\
\hline № образца & MN-09-1603 & MN-10-1723 & MN-10-1726 & MN-10-1728 & MN-10-1739 & MN-09-1570 & MN-09-1407 \\
\hline $\mathrm{SiO}_{2}$, мас. \% & 44.41 & 44.03 & 43.71 & 43.58 & 44.36 & 42.38 & 52.21 \\
\hline $\mathrm{TiO}_{2}$ & 2.82 & 3.29 & 2.91 & 3.79 & 3.15 & 3.72 & 2.45 \\
\hline $\mathrm{Al}_{2} \mathrm{O}_{3}$ & 11.43 & 10.68 & 9.65 & 10.80 & 10.83 & 12.01 & 13.67 \\
\hline $\mathrm{Fe}_{2} \mathrm{O}_{3}$ & 3.04 & 4.89 & 4.72 & 4.22 & 4.21 & 5.43 & 1.11 \\
\hline $\mathrm{FeO}$ & 9.36 & 7.97 & 7.48 & 9.04 & 8.58 & 8.56 & 9.33 \\
\hline $\mathrm{MnO}$ & 0.17 & 0.16 & 0.16 & 0.17 & 0.16 & 0.18 & 0.13 \\
\hline MgO & 11.50 & 11.36 & 15.81 & 12.74 & 11.40 & 8.86 & 7.65 \\
\hline $\mathrm{CaO}$ & 9.11 & 9.51 & 8.54 & 8.83 & 9.66 & 9.92 & 8.43 \\
\hline $\mathrm{Na}_{2} \mathrm{O}$ & 3.45 & 3.48 & 3.36 & 3.14 & 3.82 & 4.69 & 3.42 \\
\hline $\mathrm{K}_{2} \mathrm{O}$ & 2.01 & 1.31 & 0.80 & 2.32 & 2.01 & 0.92 & 0.82 \\
\hline $\mathrm{P}_{2} \mathrm{O}_{5}$ & 1.01 & 0.94 & 0.84 & 0.85 & 0.84 & 1.05 & 0.46 \\
\hline $\mathrm{H}_{2} \mathrm{O}^{-}$ & 0.39 & 0.57 & 0.33 & 0.08 & 0.19 & 0.40 & 0.07 \\
\hline $\mathrm{H}_{2} \mathrm{O}^{+}$ & 1.50 & 1.93 & 1.78 & 0.67 & 0.95 & 1.6 & 0.5 \\
\hline Сумма & 100.20 & 100.12 & 100.09 & 100.23 & 100.16 & 99.8 & 100.2 \\
\hline Sc, мКг/Г & 19.2 & 17.7 & 18.1 & 17.7 & 17.9 & 23.9 & 19.8 \\
\hline $\mathrm{V}$ & 202 & 228 & 239 & 223 & 231 & 245 & 207 \\
\hline $\mathrm{Cr}$ & 445 & 425 & 739 & 415 & 367 & 166 & 241 \\
\hline Co & 62 & 65 & 104 & 65 & 61 & 61 & 54 \\
\hline $\mathrm{Ni}$ & 297 & 413 & 589 & 402 & 358 & 171 & 166 \\
\hline $\mathrm{Rb}$ & 41.1 & 10.2 & 30.0 & 31.1 & 33.9 & 21.5 & 27.8 \\
\hline $\mathrm{Sr}$ & 1200 & 948 & 801 & 781 & 947 & 1237 & 619 \\
\hline $\mathrm{Y}$ & 35.1 & 26.1 & 23.4 & 27.2 & 27.2 & 35.1 & 25.8 \\
\hline $\mathrm{Zr}$ & 308 & 255 & 206 & 245 & 234 & 376 & 148 \\
\hline $\mathrm{Nb}$ & 89 & 69 & 62 & 57 & 72 & 104 & 35 \\
\hline Cs & 0.66 & 0.80 & 0.53 & 0.45 & 0.49 & 1.53 & 0.30 \\
\hline $\mathrm{Ba}$ & 755 & 635 & 536 & 453 & 707 & 783 & 345 \\
\hline $\mathrm{La}$ & 67 & 47 & 40 & 41 & 51 & 69 & 26 \\
\hline $\mathrm{Ce}$ & 135 & 97 & 79 & 89 & 104 & 137 & 57 \\
\hline $\mathrm{Pr}$ & 15.1 & 11.3 & 9.4 & 10.6 & 11.9 & 15.2 & 6.9 \\
\hline $\mathrm{Nd}$ & 62 & 47 & 40 & 45 & 48 & 63 & 29 \\
\hline Sm & 12.9 & 9.9 & 8.2 & 9.8 & 10.0 & 13.1 & 7.3 \\
\hline $\mathrm{Eu}$ & 3.9 & 3.2 & 2.5 & 3.2 & 3.3 & 4.1 & 2.4 \\
\hline Gd & 11.4 & 9.1 & 7.6 & 9.3 & 9.4 & 11.8 & 7.2 \\
\hline $\mathrm{Tb}$ & 1.5 & 1.1 & 1.0 & 1.1 & 1.1 & 1.6 & 1.0 \\
\hline Dy & 7.0 & 6.2 & 5.0 & 6.6 & 6.6 & 7 & 5 \\
\hline Ho & 1.3 & 0.9 & 0.7 & 0.9 & 0.9 & 1.3 & 0.9 \\
\hline Er & 2.9 & 2.2 & 1.9 & 2.3 & 2.3 & 2.9 & 2.3 \\
\hline $\mathrm{Yb}$ & 1.8 & 1.5 & 1.1 & 1.6 & 1.6 & 1.8 & 1.7 \\
\hline $\mathrm{Lu}$ & 0.27 & 0.18 & 0.15 & 0.18 & 0.18 & 0.29 & 0.22 \\
\hline $\mathrm{Hf}$ & 6.5 & 5.3 & 5.4 & 5.2 & 5.0 & 8.3 & 3.9 \\
\hline $\mathrm{Ta}$ & 4.7 & 6.3 & 3.8 & 3.7 & 4.5 & 6.1 & 2.1 \\
\hline $\mathrm{Pb}$ & 5.1 & 2.8 & 1.4 & 2.1 & 2.6 & 13.7 & 3.6 \\
\hline Th & 7.5 & 6.8 & 4.7 & 5.2 & 7.7 & 8.7 & 3.8 \\
\hline $\mathrm{U}$ & 1.81 & 0.90 & 1.11 & 1.28 & 1.70 & 1.32 & 0.41 \\
\hline
\end{tabular}

ные тренды (рис. 6).

Иные вариации обнаруживают несовместимые элементы. В наиболее магнезиальном базальте определены низкие концентрации Zr (206 мкг/г) и Rb (30 мкг/г). В породах высокомагнезиального тренда MN-10-1728 и MN-09-1573 концентрации Zr и Rb повышаются. B двух образцах определены пониженные концентрации Rb (18.7 и 10.2 мкг/г). Эти образцы относятся к низкокалиевой подгруппе высокомагнезиальных пород. Концентрации Rb умеренномагнезиальных пород низкокалиевого тренда также пониженные. Основная группа высокомагнезиальных лав сопоставляется по содержаниям Rb с породами главного умереннокалиевого тренда умеренномагнезиальных лав. Соответственно, в породах высококалиевого тренда концентрации Rb возрастают (рис. 7).

Вариации редкоземельных элементов высокомагнезиальных пород не выходят за пределы интервала вариаций умеренномагнезиальных пород. Их спектры образуют компактную группу в середине общего поля базальтов Дариганги. Спектр наиболее магнезиальной породы отличается от спектров основной группы магнезиальных пород слабым относительным обеднением тяжелыми редкоземельными элементами от Но до Lu. 


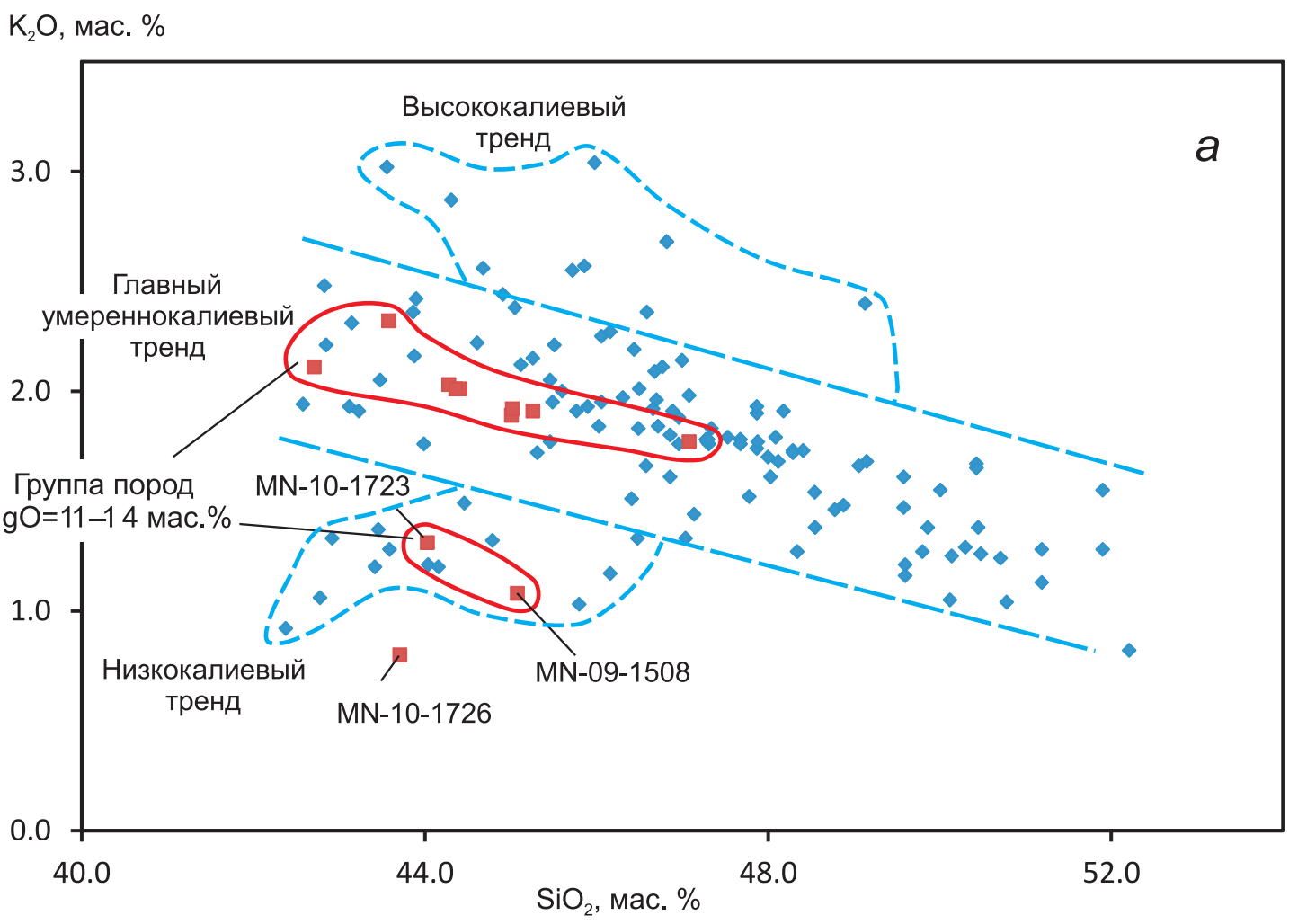

$\mathrm{K} \mathrm{O}_{2} \mathrm{Na}_{2} \mathrm{O}$

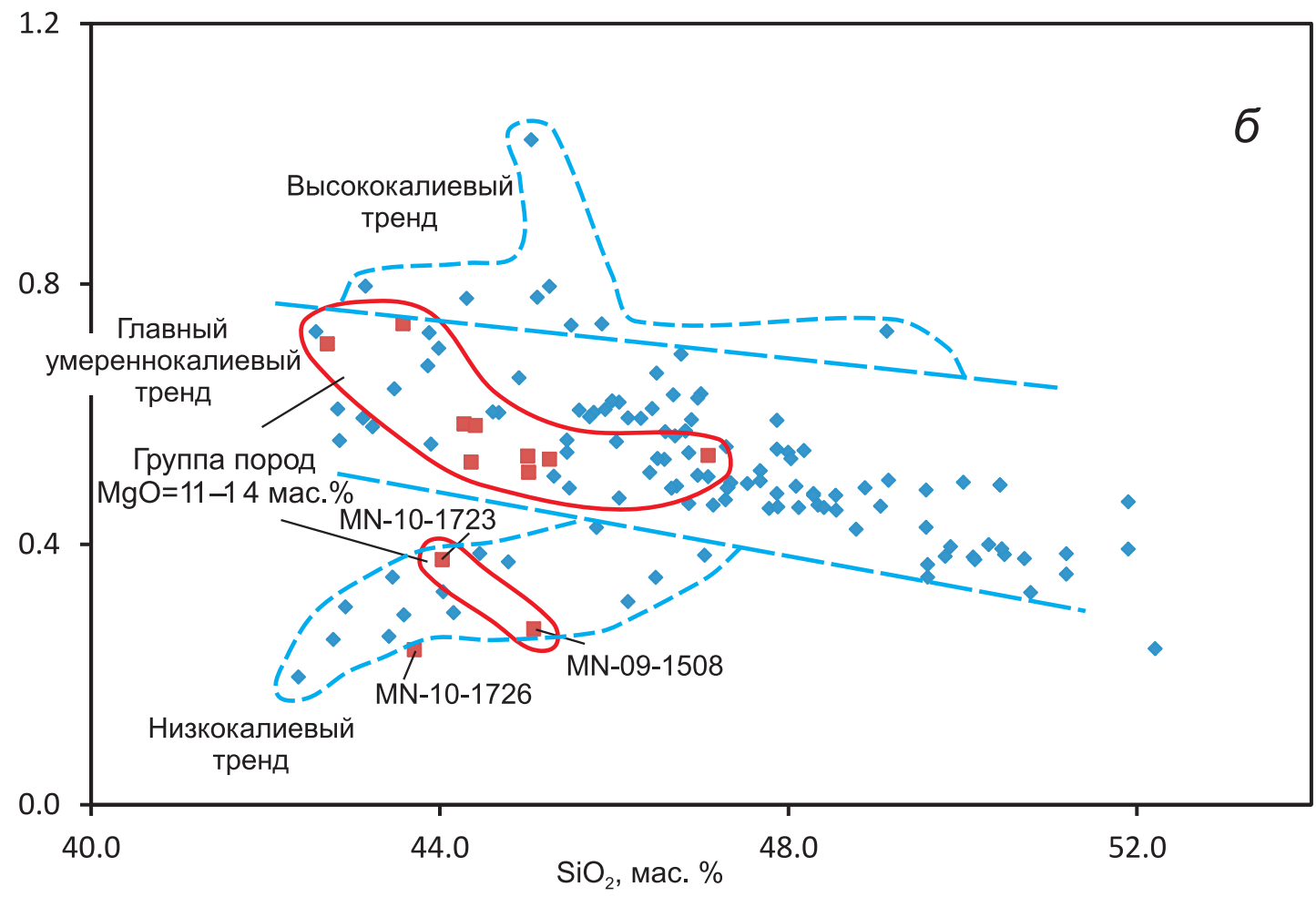

Рис. 4. Соотношения высокомагнезиальной и умеренномагнезиальной групп пород Дариганского поля на диаграммах $\mathrm{K}_{2} \mathrm{O}-\mathrm{SiO}_{2}(a)$ и $\mathrm{K}_{2} \mathrm{O} / \mathrm{Na}_{2} \mathrm{O}-\mathrm{SiO}_{2}$ (б). Усл. обозн. см. рис. 3. В умеренномагнезиальной группе голубыми субпараллельными штриховыми линиями выделен главный умереннокалиевый тренд, сопровождающийся боковыми второстепенными низкокалиевым и высококалиевым трендами, протягивающимися в области пониженных содержаний $\mathrm{SiO}_{2}$.

Fig. 4. $\mathrm{K}_{2} \mathrm{O}$ vs. $\mathrm{SiO}_{2}(a)$ and $\mathrm{K}_{2} \mathrm{O} / \mathrm{Na}_{2} \mathrm{O}$ vs. $\mathrm{SiO}_{2}$ (б) for high- and moderate-Mg groups of volcanic rocks from the Dariganga field. See the legend in Fig. 3. In the moderate-Mg group, blue subparallel dashed lines show the main moderate-K trend associated with lateral low-and high-K trends extended towards the low- $\mathrm{SiO}_{2}$ part of the diagram. 


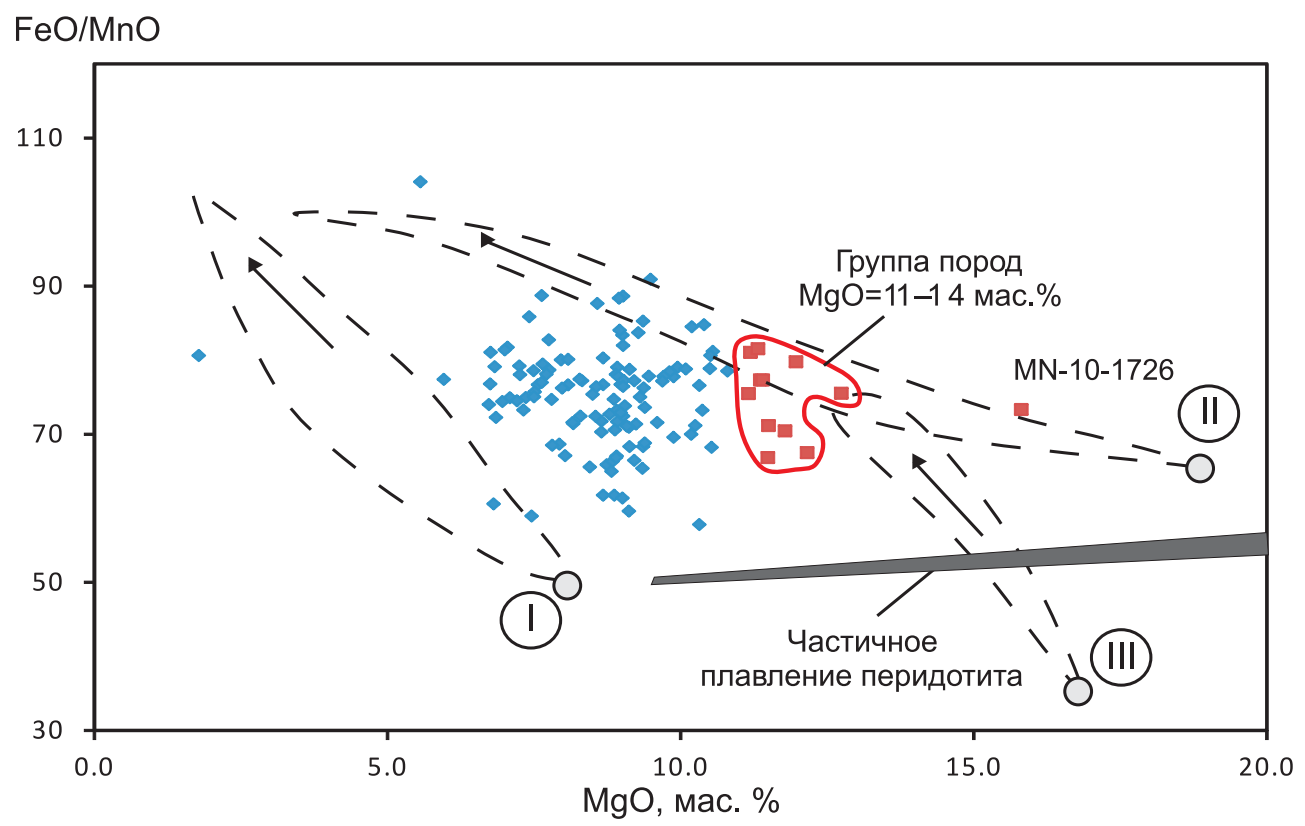

Рис. 5. Соотношения высокомагнезиальной и умеренномагнезиальной групп пород Дариганского поля на диаграмме $\mathrm{FeO} / \mathrm{MnO}-\mathrm{MgO}$. Усл. обозн. см. рис. 3. Приведены тренды соотношений продуктов малой и высокой степеней частичного плавления различных субстратов: I-III - исходные составы перидотитов и пироксенитов (кружки) и направления эволюции их выплавок (стрелки) при снижении степени частичного плавления, по экспериментальным данным [Pertermann, Hirschmann, 2003; Keshav et al., 2004; Sobolev et al., 2007; Herzberg, 2011]: I - низкомагнезиальный пироксенит, II - высокомагнезиальный пироксенит, III - магнезиальный пироксенит с пониженным $\mathrm{FeO} / \mathrm{MnO}$.

Fig. 5. FeO/MnO vs. MgO diagram for high- and moderate-Mg groups of rocks from the Dariganga volcanic field. See the legend in Fig. 3. Trends with low and high degrees of partial melting of various substrates: I-III - initial compositions of peridotites and pyroxenites (circles) and directions of evolution of their liquids (arrows) with the decreasing degree of partial melting, according to experimental data [Pertermann, Hirschmann, 2003; Keshav et al., 2004; Sobolev et al., 2007; Herzberg, 2011]: I - low-Mg pyroxenite; II - high-Mg pyroxenite; III - Mg-pyroxenite with low $\mathrm{FeO} / \mathrm{MnO}$.

Концентрации РЗЭ в этом базальте сравнительно низкие (рис. 8, a). Подобным образом соотносятся между собой и спектры микроэлементов вулканических пород, нормированных к составу недифференцированной мантии и выстроенных в порядке несовместимости. Исключение составляют аномально низкие концентрации $\mathrm{Rb}, \mathrm{K}$ и $\mathrm{Pb}$ и повышенные содержания $\mathrm{Cs}$, полученные для наиболее магнезиального базальта (рис. 8, б).

\section{5. ПРОСТРАНСТВЕННОЕ РАСПРЕДЕЛЕНИЕ ВЫСОКОМАГНЕЗИАЛЬНЫХ ЛАВ}

Высокомагнезиальные лавы Дариганского поля образуют субширотную и две северо-восточные (CB) 30ны (рис. 9). Субширотная зона протрассирована от вулкана Авгойт-Ула на западе до вулкана Сэнджитийн-Ундэр на востоке, на расстояние не менее 110 км. Одна из СВ-зон сочленяется с западным окончанием субширотной зоны на вулкане Авгойт-Ула и протягивается на северо-восток до вулкана Хорцо-Ула, на расстояние не менее 90 км. Другая СВ-зона пересекает субширотную на вулканах Будун-Толгой, Хагдат-Толгой и Сэнджитийн-Ундэр. На южном окончании этой
СВ-зоны находятся высокомагнезиальные лавы группы вулканов Бага-Ула, на северном окончании - лавы вулкана Сулхар. Протяженность СВ-зоны Бага-Ула Сулхар сопоставима с протяженностью СВ-зоны Авгойт-Ула - Хорцо-Ула. Ширина выделенных зон высокомагнезиальных базальтов составляет 10-20 км.

СВ-зона Авгойт-Ула - Хорцо-Ула находится в северо-западной части поля, а СВ-зона Бага-Ула - Сулхар - в юго-восточной части. Субширотная зона Авгойт-Ула - Сэнджитийн-Ундэр расположена в основном в юго-восточной части поля и протягивается в западную часть. На пересечениях субширотной зоны зонами северо-восточного простирания находятся вулканы с лавами, содержащими включения граната.

\section{6. ОБСУЖДЕНИЕ РЕЗУЛЬТАТОВ}

\section{1. СООТНОШЕНИЯ ВЫСОКОМАГНЕЗИАЛЬНЫХ И УМЕРЕННОМАГНЕЗИАЛЬНЫХ ПОРОД НА КАЙНОЗОЙСКИХ ВУЛКАНИЧЕСКИХ ПОЛЯХ АЗИИ}

В Азии высокомагнезиальные и умеренномагнезиальные лавы либо разобщены во времени и пространстве, либо тесно связаны между собой. Так, рассредо- 
I.S. Chuvashova et al.: High-Mg lavas from the Dariganga volcanic field...
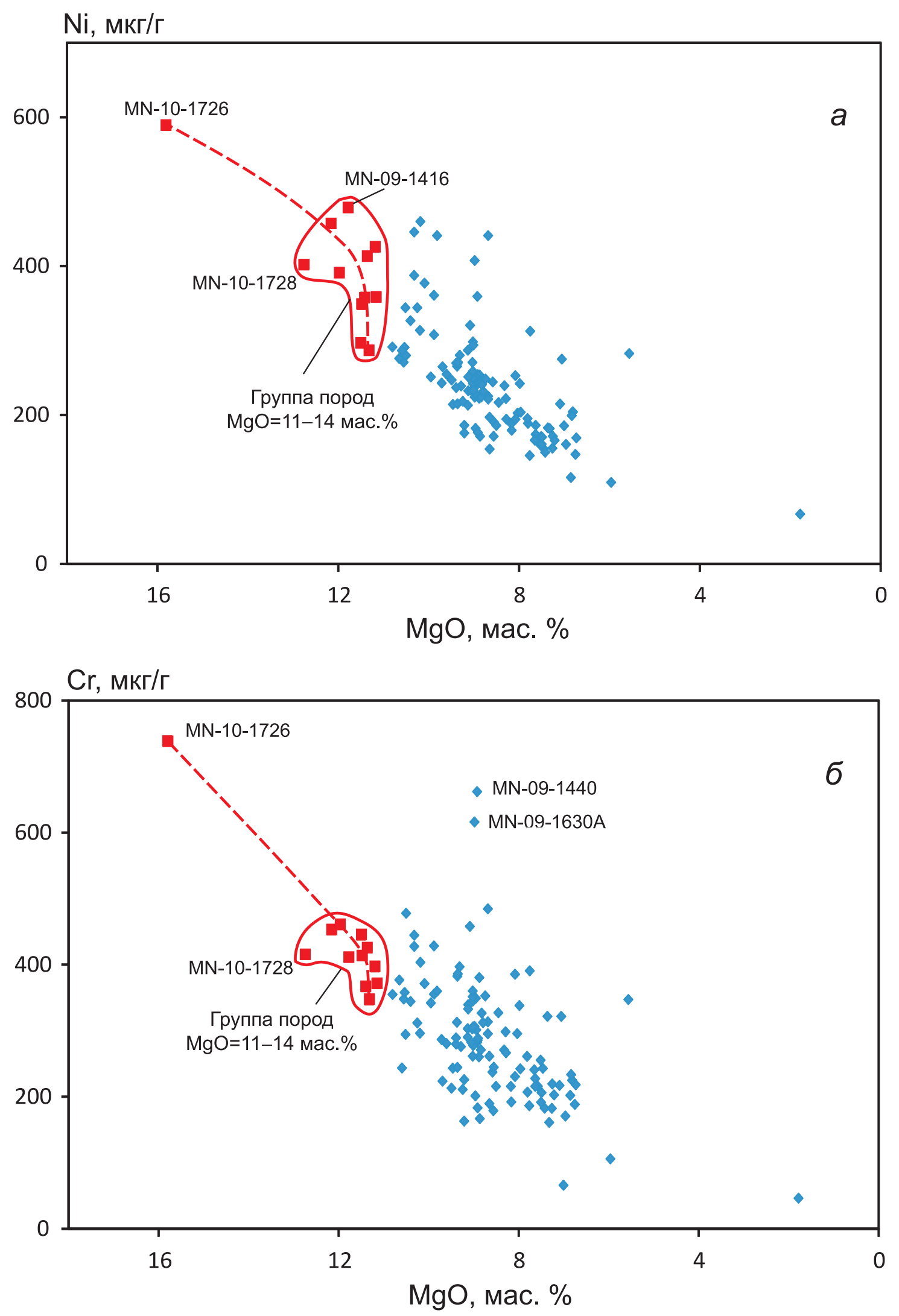

Рис. 6. Соотношения высокомагнезиальной и умеренномагнезиальной групп пород Дариганского поля на диаграммах $\mathrm{Ni}-\mathrm{MgO}(a)$ и $\mathrm{Cr}-\mathrm{MgO}($ (). Усл. обозн. см. рис. 3.

Fig. 6. $\mathrm{Ni}$ vs. $\mathrm{MgO}(a)$ and $\mathrm{Cr}$ vs. $\mathrm{MgO}$ (б) diagrams for high- and moderate-Mg groups of rocks from the Dariganga field. See the legend in Fig. 3. 

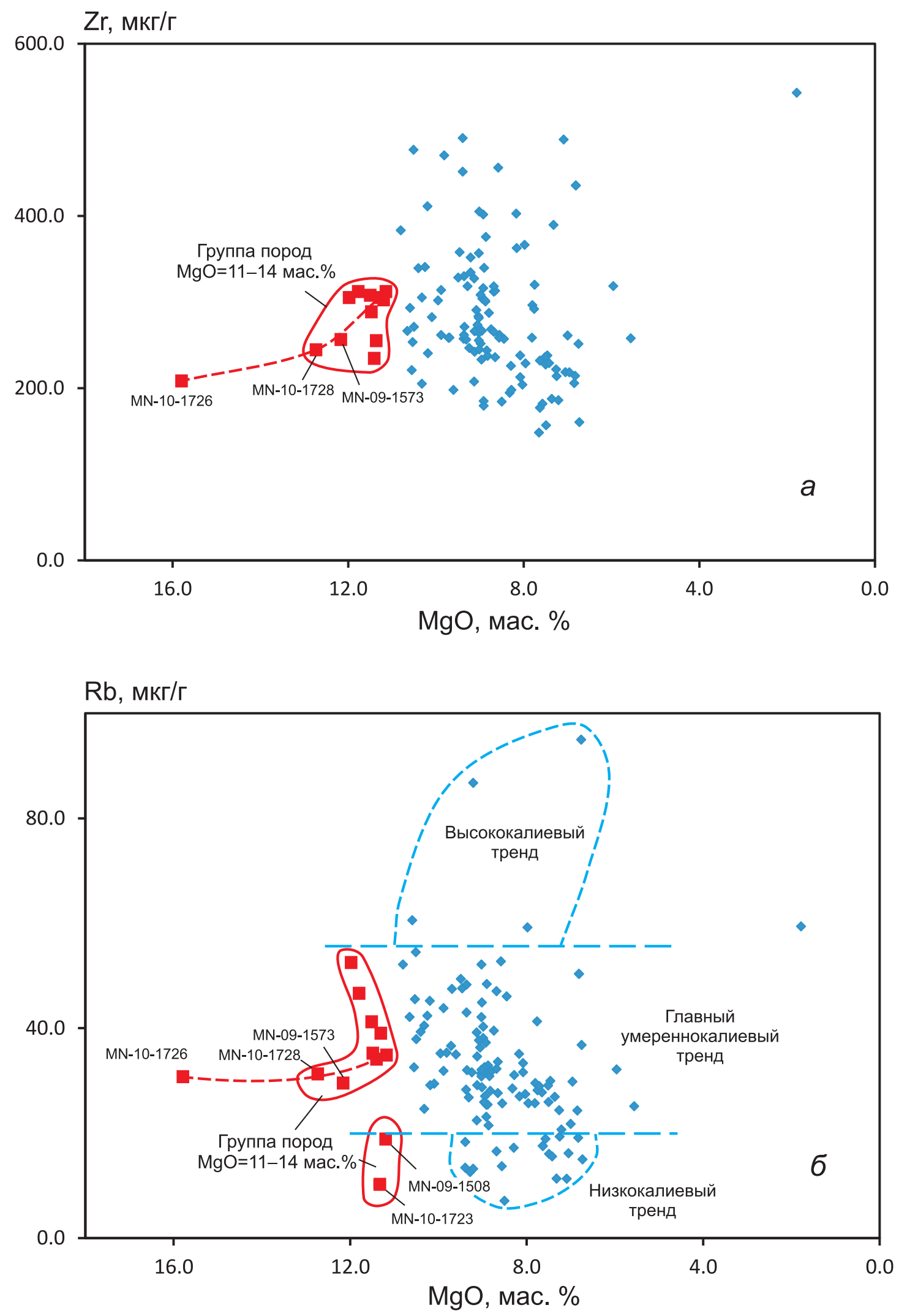

Рис. 7. Соотношения высокомагнезиальной и умеренномагнезиальной групп пород Дариганского поля на диаграммах $\mathrm{Zr}-\mathrm{MgO}$ ( $а$ ) и $\mathrm{Rb}$ - MgO (б). Усл. обозн. см. рис. 3.

Fig. 7. Zr vs. MgO (a) and Rb vs. MgO (б) for high- and moderate-Mg groups of rocks from the Dariganga field.. See the legend in Fig. 3. 
I.S. Chuvashova et al.: High-Mg lavas from the Dariganga volcanic field...
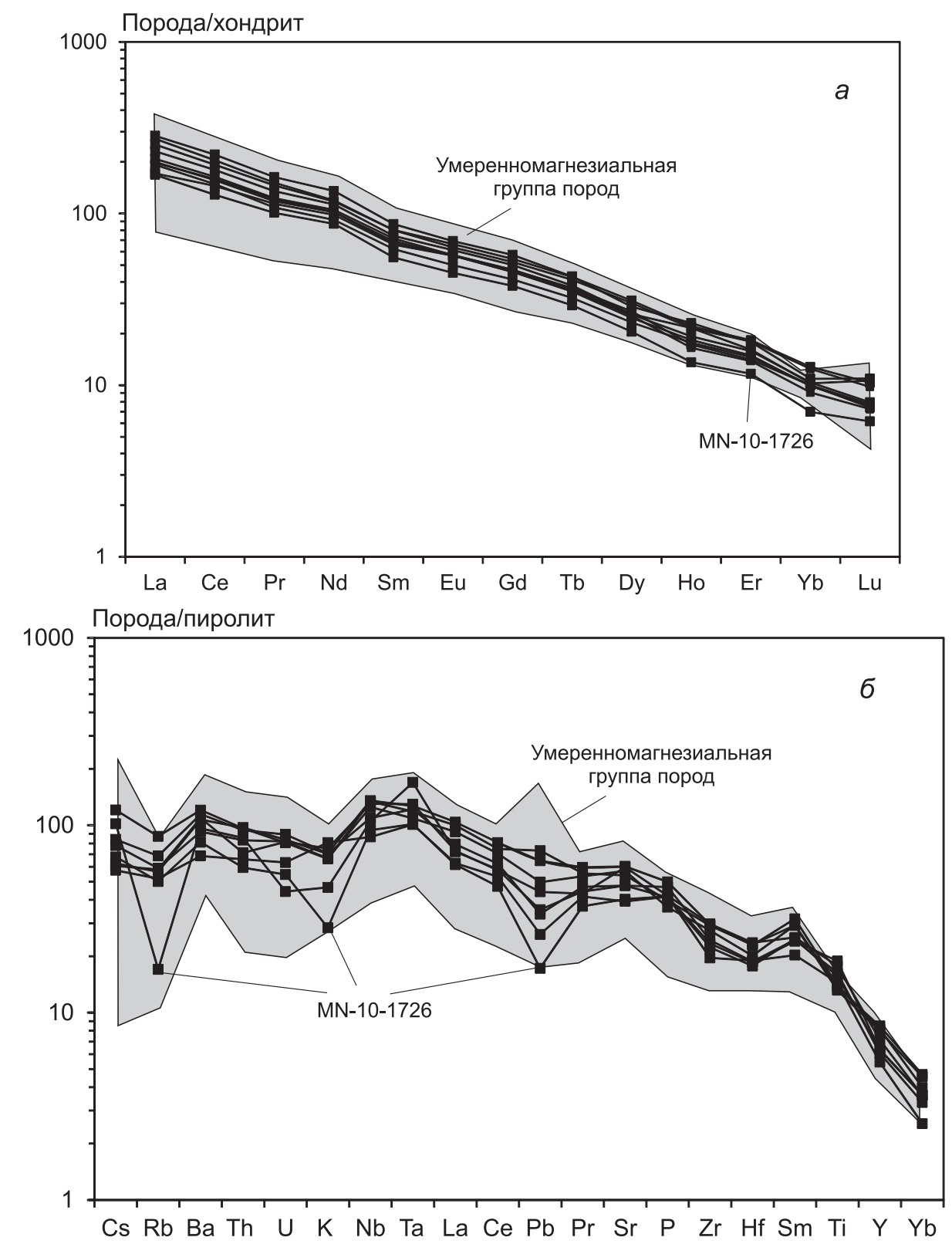

Рис. 8. Соотношения высокомагнезиальной и умеренномагнезиальной групп пород Дариганского поля на диаграммах редкоземельных спектров, нормированных к составу хондрита $(a)$, и спектров микроэлементов вулканических пород, нормированных к составу недифференцированной мантии и выстроенных в порядке несовместимости (б). Для нормирования использованы составы из работы [Sип, McDonough, 1989].

Fig. 8. Rare earth spectra normalized to the composition of chondrite (a) and the spectra of incompatible trace elements normalized to the composition of the undifferentiated mantle (б) for high- and moderate-Mg groups of rocks from the Dariganga field. Normalization is after [Sun, McDonough, 1989].

точенные извержения высокомагнезиальных оливиновых меланефелинитов (MgO=11-13 мас. \%) проявились в центральной и северо-восточной частях хр. Хэнтэй около 3 млн лет назад без сопровождения менее магнезиальными лавами [Rasskazov, 1987]. В Центральной Монголии и Восточном Саяне, наоборот, высокомагнезиальные лавы не обнаружены, а все проанализированные образцы имеют умеренномагнезиальный состав [Kepezhinskas, 1979; Rasskazov, 1993; Rasskazov et al., 2012]).
В ряде случаев извержения высокомагнезиальных лав обозначали начало вулканической деятельности территорий, продолжавшейся затем извержениями умеренномагнезиальных лав миллионы лет, иногда до полутора десятка миллионов лет. Так, на Удоканском поле Северного Забайкалья первые извержения представлены извержениями оливиновых мелалейцититов около 14 млн лет назад, а затем, начиная с 8 млн лет назад до голоцена включительно, - умеренно- и высокощелочными дифференцированными сериями 


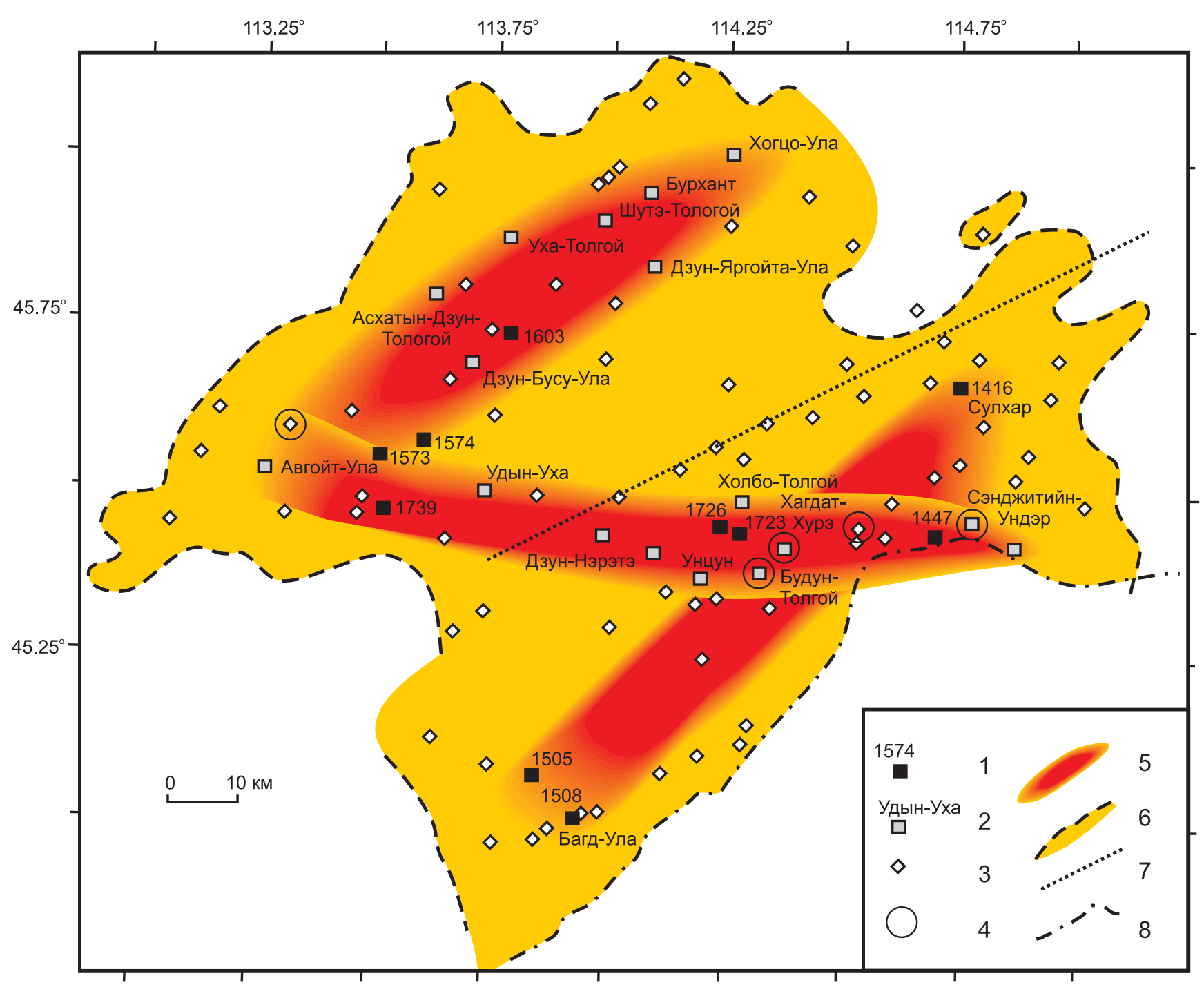

Рис. 9. Схема пространственного распределения высокомагнезиальной (высокотемпературной) и умеренномагнезиальной (с меньшими температурами) групп пород Дариганского поля. 1 - высокомагнезиальные породы (таблица); 2-3 - высокомагнезиальные (2) и умеренномагнезиальные (3) породы, по данным из работы [Saltykovsky, Genshaft, 1985] и новым данным авторов; 4 - находки включений граната [Saltykovsky, Genshaft, 1985]; 5 - зона высокомагнезиальных лав; 6 - контур вулканического поля - распространение умеренномагнезиальных лав; 7 - граница между территориями с разнонаправленными вулканическими линиями, ориентированными на северо-восток (азимут $45^{\circ}$ ) и восток-северо-восток (азимут $70^{\circ}$ ) (см. рис. 1 ); 8 - государственная граница.

Fig. 9. Spatial distribution of high-Mg (high temperature) and moderate-Mg (lower temperature) groups of rocks within the Dariganga field. $1-$ high-Mg rocks (Table); 2-3 - high-Mg (2) and moderate-Mg (3) rocks from [Saltykovsky, Genshaft, 1985] and new unpublished data of authors; 4 - garnet inclusions [Saltykovsky, Genshaft, 1985]; 5 - zone of high-Mg lavas; 6 - the volcanic field's countour (distribution of moderate-Mg lavas); 7 - boundary between areas with volcanic lines oriented to the north-east (azimuth $45^{\circ}$ ) and east-north-east (azimuth $70^{\circ}$ ) (see Fig. 1 ); 8 - the state border.

щелочной оливиновый базальт - трахит и базанит нефелиновый муджиерит. В разрезах вулканических толщ отмечены единичные лавовые слои высокомагнезиального состава [Rasskazov, 1985; Rasskazov et al., 1997]. На Шкотовском поле Южного Приморья после продолжительного перерыва (начавшегося 22-21 млн лет назад) около 15-14 млн лет назад имела место фаза извержений высокомагнезиальных оливиновых лейцититов, а последующий вулканизм различного состава, от базальтов до андезитов, продолжался с 13 до 3 млн лет назад [Rasskazov et al., 2003, 2010; Sakhno et al., 2004]. На поле Келуо в Северо-Восточном Китае извержения высокомагнезиальных оливиновых лейцититов произошли около 9.6 млн лет назад, сменившись около 7 млн лет назад извержениями менее магнезиальных лав калиевой и переходной к калинатровой серий [Zhang et al., 1995; Rasskazov et al., 2012].

На Дариганском поле высокомагнезиальные лавы сконцентрированы в линейных зонах при общем фоновом распределении умеренномагнезиальных лав. Для выяснения особенностей, способствовавших про- 


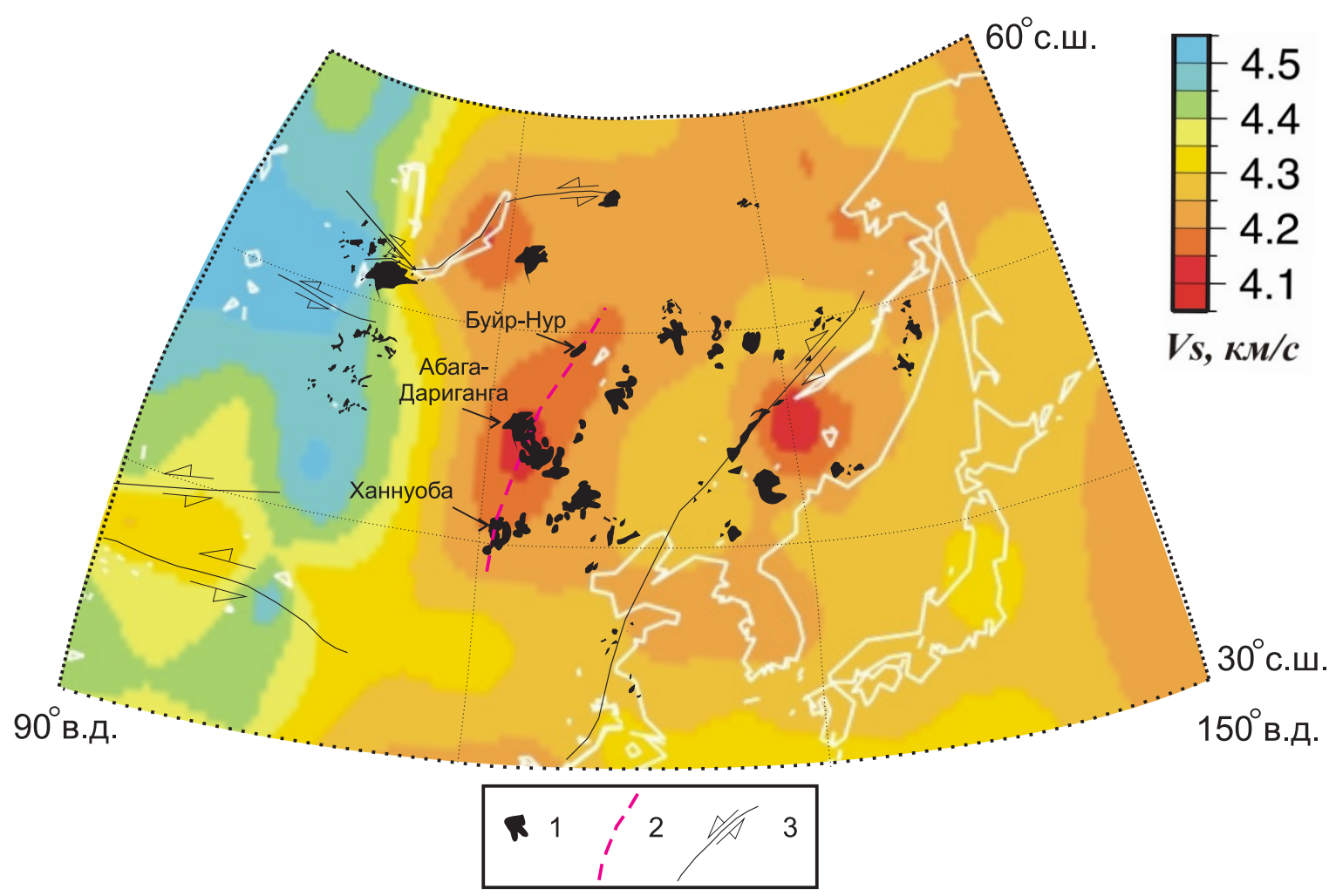

Рис. 10. Пространственные соотношения вулканических полей Дариганга, Ханнуоба и Буйр-Нур с Восточно-Монгольской низкоскоростной аномалией, выраженной в глубинном скоростном срезе 250 км. 1 - позднекайнозойские вулканические поля; 2 - осевая линия Восточно-Монгольской низкоскоростной аномалии; 3 - крупные сдвиговые разломы. Вулканические поля Дариганга, Ханнуоба и БуйрНур пространственно соответствуют осевой части Восточно-Монгольской низкоскоростной аномалии. Вулканические поля наложены на скоростной срез 250 км модели S-волн [Yanovskaya, Kozhevnikov, 2003], в котором локальная Восточно-Монгольская низкоскоростная аномалия проявлена наиболее отчетливо [Rasskazov et al., 2003].

Fig. 10. Spatial location of the Dariganga, Hannuoba and Buyr Noor volcanic fields relative to the East Mongolian low-velocity anomaly detected at the level of $250 \mathrm{~km} .1$ - the Late Cenozoic volcanic fields; 2 - the axial line of the East Mongolian low-velocity anomaly; 3 - large strike-slip faults. The Dariganga, Hannuoba and Buyr Noor volcanic fields are spatially coincident with the axial part of the East Mongolian low-velocity anomaly. The volcanic fields are placed on the velocity level $250 \mathrm{~km}$ of the S-wave model [Yanovskaya, Kozhevnikov,2003], at which the East Mongolian local low-velocity anomaly is manifested most clearly [Rasskazov et al., 2003].

явлению высокомагнезиального магматизма линейных зон, обратимся сначала к модели магматизма провинции Ханнуоба Северо-Восточного Китая, а затем проведем сравнительный анализ данных по составу вулканических пород полей Дариганга и Ханнуоба.

\section{2. МОДЕЛЬНЫЕ ПЕТРОГЕНЕТИЧЕСКИЕ ПОСТРОЕНИЯ ДЛЯ ВУЛКАНИЧЕСКИХ ПОРОД ПОЛЯ ХАННУОБА}

В модели S-волн [Yanovskaya, Kozhevnikov, 2003] вулканической полосе Абага-Дариганга соответствует Восточно-Монгольская низкоскоростная аномалия, вытянутая в направлении север-северо-восток и резко выраженная на глубине 250 км [Rasskazov et al., 2003]. Вулканическое поле Ханнуоба пространственно соответствует ее южной части и вместе с вулканическими полями Дариганга и Буйр-Нур представляет крайние западные вулканические проявления восточной окраины Азии (рис. 10).

Лавовые слои миоценового возраста толеитового, щелочно-базальтового и переходного состава на поле Ханнуоба беспорядочно перемежаются между собой. Среди щелочных базальтов выделяются примитивные и эволюционированные (evolved) [Zhi et al., 1990; Song et al., 1990]. В первичной интерпретации авторов цитированных работ микроэлементные и изотопные характеристики базальтов Ханнуобы сопоставлялись с характеристиками конечных компонентов океанических базальтов. Щелочные базальты рассматривались как выплавки из астеносферы, а толеитовые - как компонент EMI из астеносферного апвеллинга или континентальной литосферной мантии. По аналогии с соотношениями общего обогащенного астеносферного компонента с компонентами литосферы и слэба в лавах Северо-Восточного Китая на диаграммах изотопов Sr и Pb [Rasskazov et al., 2011, 2012], мы предполагаем, что в лавах провинции Ханнуоба также отражена динамика двух уровней: 1) границы литосферы и астеносферы и 2) подлитосферной части мантии.

$\mathrm{B}$ координатах изотопов $\mathrm{Sr}$ и $\mathrm{Pb}$ (рис. 11) фигура- 


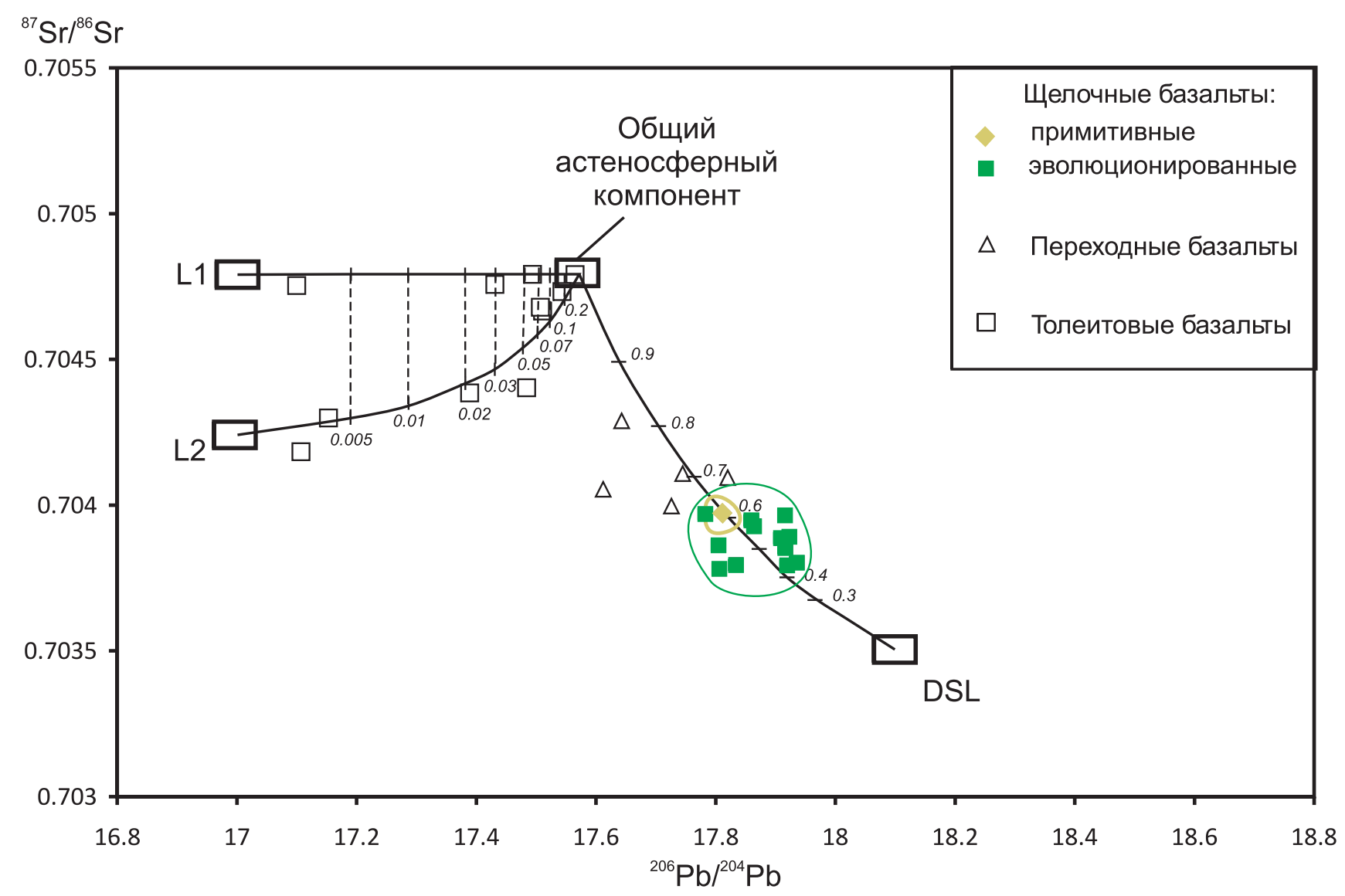

Рис. 11. Соотношение $\left({ }^{87} \mathrm{Sr} /{ }^{86} \mathrm{Sr}\right)_{0}-{ }^{206} \mathrm{~Pb} /{ }^{204} \mathrm{~Pb}$ в миоценовых вулканических породах провинции Ханнуоба Северного Китая. Показаны рассчитанные кривые смешения общего изотопно-обогащенного астеносферного компонента с изотопно-обогащенным и обедненным компонентами литосферной мантии L1, L2 и подлитосферным изотопно-обедненным компонентом DSL. Цифрами обозначены доли общего компонента. Коэффициенты распределения (включая рис. 12): Ol, Opx, Gt - [Halliday et al., 1995]; Cpx - [Hart, Dunn, 1993] (Yb, La, Sr), [Hauri et al., 1994] (Pb); Ар - [Ionov et al., 1997]. Использованы данные из работы [Song et al., 1990].

Fig. 11. $\left({ }^{87} \mathrm{Sr} /{ }^{86} \mathrm{Sr}\right)_{0}$ vs. ${ }^{206} \mathrm{~Pb} /{ }^{204} \mathrm{~Pb}$ for the Miocene volcanic rocks from Hannuoba Province, Northern China. Calculated curves show mixing of the common isotopically-enriched asthenospheric component with isotopically-enriched and depleted components of the lithospheric mantle (L1 and L2) and the sub-lithospheric isotopically-depleted component (DSL). Numerals indicate shares of the total component. Distribution coefficients (including those in Fig. 12): Ol, Opx, Gt [Halliday et al., 1995]; Cpx [Hart, Dunn, 1993] (Yb, La, Sr), [Hauri et al., 1994] (Pb); Ap [Ionov et al., 1997]. Data from [Song et al., 1990].

тивные точки толеитовых базальтов Ханнуобы образуют тренды, подобные трендам калинатровых выплавок вулканического поля Нуоминхе западной части провинции Хелунцзян Северо-Восточного Китая и синтетическому тренду калиевых выплавок из подошвы литосферы центральной части этой же провинции. Последние имеют место на различных вулканах полей Келуо и Удалианчи. Тренд щелочных и переходных базальтов Ханнуобы подобен синтетическому тренду калинатровых выплавок из слэбового материала, погруженного в конвектирующую астеносферу. Эти выплавки распространены на полях Северо-Восточного Китая: Чанбайшан, Лонг-Ганг, Жингпоху и Куандиан.

Изотопно-обедненный материал Ханнуобы имеет подлитосферное (наиболее глубинное) происхождение и выступает в смешении с материалом конвектирующей астеносферы. Мы связываем источник щелочных базальтов Ханнуобы с Восточно-Монгольской низко- скоростной аномалией, установленной в модели Sволн на глубине около 250 км. Предполагая в данном случае зарождение щелочно-базальтовых магм из достаточно глубокого источника, мы рассматриваем его материал как компонент обедненной подлитосферной (depleted sub-lithospheric или DSL) мантии. Компонент астеносферы характеризуем отношениями $\left({ }^{87} \mathrm{Sr} /{ }^{86} \mathrm{Sr}\right)_{0}=$ $=0.704791, \quad{ }^{143} \mathrm{Nd} /{ }^{144} \mathrm{Nd}=0.512806,{ }^{206} \mathrm{~Pb} /{ }^{204} \mathrm{~Pb}=17.565$, ${ }^{207} \mathrm{~Pb} /{ }^{204} \mathrm{~Pb}=15.458,{ }^{208} \mathrm{~Pb} /{ }^{204} \mathrm{~Pb}=37.619$.

По результатам представительных аналитических работ [Song et al., 1990], астеносферный компонент Ханнуобы определяется в группе толеитовых базальтов составом обр. D-5 с максимальными значениями отношений $\left({ }^{87} \mathrm{Sr} /{ }^{86} \mathrm{Sr}\right)_{0}=0.704791, \quad{ }^{206} \mathrm{~Pb} /{ }^{204} \mathrm{~Pb}=17.565$, ${ }^{207} \mathrm{~Pb} /{ }^{204} \mathrm{~Pb}=15.458,{ }^{208} \mathrm{~Pb} / 204 \mathrm{~Pb}=37.619$ и минимальным значением отношения ${ }^{143} \mathrm{Nd} /{ }^{144} \mathrm{Nd}=0.512806$. В работах [Basu et al., 1991; Tatsumoto et al., 1992] приведено более высокое $-\left({ }^{87} \mathrm{Sr} /{ }^{86} \mathrm{Sr}\right)_{0}=0.70497-$ и более низкое - 
${ }^{143} \mathrm{Nd} /{ }^{144} \mathrm{Nd}=0.51268$ - для толеитового базальта обр. D-52 при сравнительно низких отношениях изотопов $\mathrm{Pb}$. Расхождение результатов измерений в двух исследованиях может быть связано с различными методиками подготовки проб для изотопного анализа. В измерениях изотопов $\mathrm{Sr}$ и $\mathrm{Nd}$ в работе [Song et al., 1990] применялась предварительная кислотная обработка проб, а в работах [Basu et al., 1991; Tatsumoto et $a l ., 1992]$ такой обработки не проводилось. Для построения модели смешения компонентов (рис. 11) используются только данные из работы [Song et al., 1990].

Выявляются отличия по пропорциям астеносферных компонентов и участвующих в смешении компонентов литосферной и подлитосферной мантии. В Северо-Восточном Китае доля астеносферного материала в литосферных выплавках под центральной частью провинции Хелунцзян не превышала 9 \%, а под территорией, расположенной восточнее, варьировалась в самых разных пропорциях. В Северном Китае (провинция Ханнуоба), наоборот, астеносферный материал в разных пропорциях смешивался с литосферным материалом (компонентами L1 и L2) и выступал в фиксированных, приблизительно равных количествах при смешении с обедненным подлитосферным материалом (компонентом DSL) (рис. 11).

На вариационной диаграмме изотопов $\mathrm{Sr}$ и $\mathrm{Pb}$ точки переходных базальтов Ханнуобы несколько смещены от линии смешения астеносферного и обедненного подлитосферного материала по направлению к линиям смешения астеносферного и литосферного материала. Смещение отражает действительно переходный характер образования этих пород - появление в гибридном астеносферно-подлитосферном материале примеси гибридного астеносферно-литосферного материала.

Сильное плавление астеносферы на границе с литосферой под провинцией Ханнуоба было вызвано влиянием подлитосферных процессов, выраженных в одновременной активности глубинного подлитосферного источника DSL. Иными словами, плавление астеносферы усилилось под подошвой литосферы вследствие привноса тепла порцией материала, которая могла быть результатом адиабатических процессов, инициированных на глубоком уровне подлитосферной мантии ( 250 км).

\section{3. СОПОСТАВЛЕНИЕ ВУЛКАНИЧЕСКИХ ПОРОД ПОЛЕЙ ХАННУОБА И ДАРИГАНГА}

Разноглубинное происхождение толеитовых и щелочных базальтов Ханнуобы подтверждается распределением точек в координатах $(\mathrm{La} / \mathrm{Yb})_{\mathrm{N}}-\mathrm{Yb}_{\mathrm{N}}$ (рис. 12 , a). Щелочные эволюционированные базальты представляют собой выплавки из источника с высоким содержанием граната, а толеитовые базальты - из безгранатового источника. Переходные базальты - производные источника с большой долей клинопироксена и малой - граната (Cpx - 30 \%, Gt - 1 \%). Для примитивных щелочных базальтов определен источник с малым содержанием граната и высоким содержанием оливина (на 10-13 \% выше, чем в источнике эволюционированных щелочных базальтов). По модели равновесного частичного плавления доля расплава в источнике толеитовых базальтов - 20-35 \%, переходных - 10-25 \%, примитивных щелочных - 5-6 \%, эволюционированных щелочных - 2-5 \%. В модельных источниках рассчитаны доли минералов (100 \%): Opx - 25 \%, Cpx, Gt, Ap - приведены на графике, остальное составляет Ol.

По малой роли граната в источнике группа щелочных примитивных базальтов резко отделена от группы щелочных эволюционированных базальтов и сближена с группами переходных и толеитовых базальтов. Из этих соотношений следует, что только эволюционированная часть щелочно-базальтовых расплавов образовалась в глубокой части мантии, а их примитивная часть явилась результатом адиабатического поднятия материала на малоглубинный уровень под подошву литосферы. Мы предполагаем, что привнос тепла, выраженный в слегка повышенных ликвидусных температурах примитивных составов, способствовал развитию процессов плавления в малоглубинной мантии на границе астеносферы и литосферы.

Охарактеризованные соотношения изотопов и микроэлементов лав Ханнуобы свидетельствуют об отчетливом проявлении активного характера мантийных процессов - активизации малоглубинной мантии вследствие поднятия глубинного материала.

Подобные магмообразующие процессы, по-видимому, имели место в миоцене-квартере и под вулканическим полем Дариганга, но реализовались иначе. В координатах $(\mathrm{La} / \mathrm{Yb})_{\mathrm{N}}-\mathrm{Yb}_{\mathrm{N}}$ выявляется равномерное распределение фигуративных точек пород между модельными линиями с содержаниями граната в источниках от 2.2 до 4.0 \% при вариациях степени частичного плавления от 0.5 до $3.0 \%$. Вся совокупность излившихся лав была производной единой области магмообразования. В отличие от мантийных источников Ханнуобы, в модельных источниках Дариганги понижено содержание клинопироксена (до 5 \%) и отсутствует апатит.

В координатах $\mathrm{La} / \mathrm{Yb}-\mathrm{MgO}$ с лавами поля Ханнуоба сопоставляются умеренномагнезиальные лавы поля Дариганга. Непрерывный рой точек перекрывает разрыв между группами эволюционированных щелочных оливиновых базальтов (EV-AOB) и примитивных щелочных оливиновых базальтов (PR-AOB) в форме углового тренда, направленного острием на высокомагнезиальные лавы Дариганги. Верхняя ветвь углового тренда достигает пространства эволюционированных щелочных базальтов поля Ханнуоба. Только три точки дариганских лав попадают в поле EV-AOB. Нижняя ветвь углового тренда перекрывает фигуративные поля PR-AOB и TRB. Далее концентрированная группа дариганских точек достигает поля TLB 

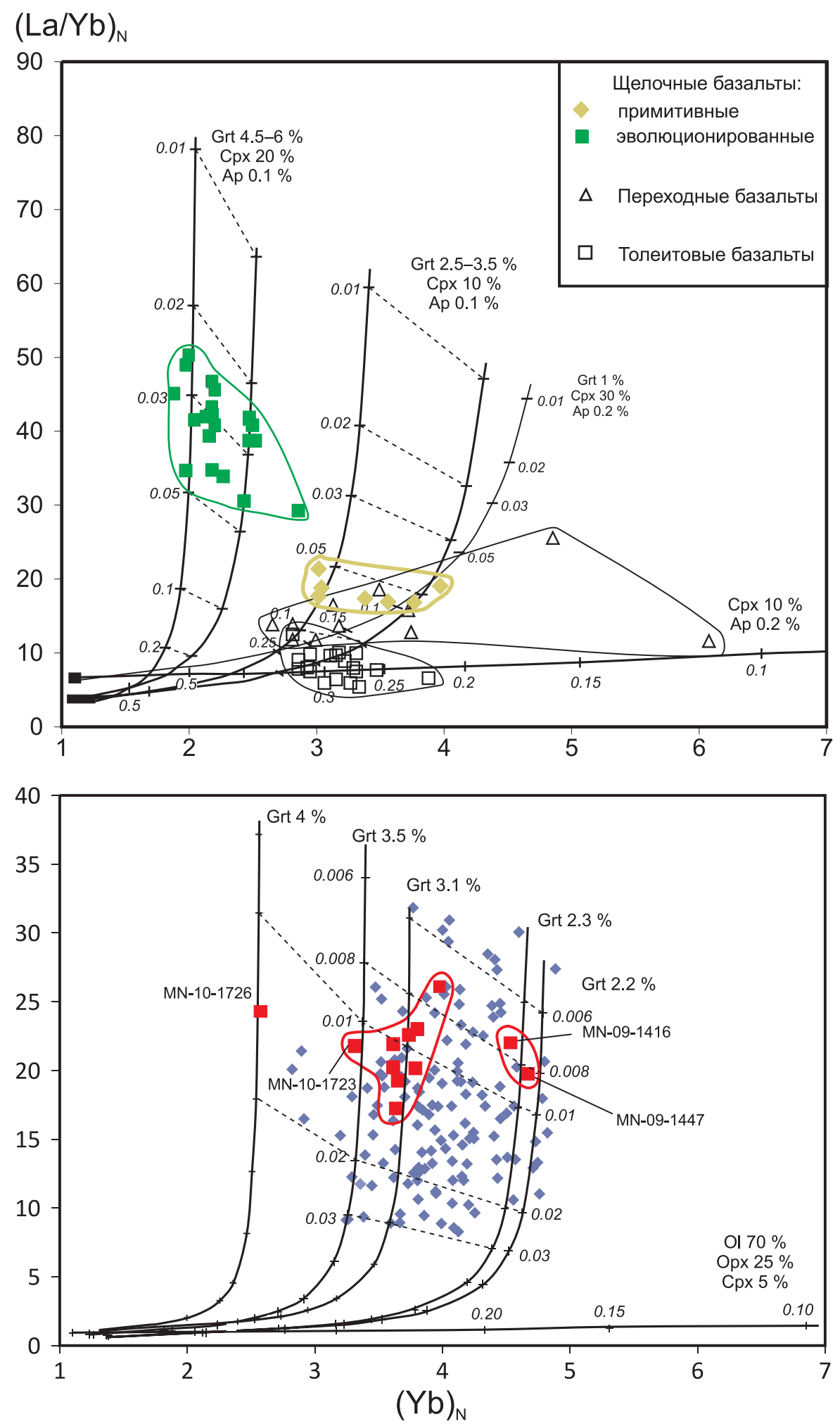

Рис. 12. Соотношение $(\mathrm{La} / \mathrm{Yb})_{\mathrm{N}}-\mathrm{Yb}_{\mathrm{N}}$ в миоценовых вулканических породах поля Ханнуоба (a) и в миоцен-четвертичных - поля Дариганга (б). Цифрами на кривых показана степень частичного плавления (F). Штриховыми линиями соединены точки с одинаковыми $\mathrm{F}$ для источников, отличающихся только содержаниями граната и оливина (см. текст). Нормирование выполнено по составу недифференцированной мантии [Sun, McDonough, 1989]. При моделировании плавления использованы коэффициенты распределения из литературных источников, приведенных на рис. 11. Использованы данные [Zhi et al., 1990] и авторов.

Fig. 12. $(\mathrm{La} / \mathrm{Yb})_{\mathrm{N}}$ vs. $\mathrm{Yb}_{\mathrm{N}}$ in the Miocene volcanic rocks from the Hannuoba field $(a)$ and in the Miocene-Quaternary volcanic rocks from the Dariganga field (б). Numerals at the curves indicate degrees of partial melting (F). Dashed lines connect points with the same values of $\mathrm{F}$ for sources, which contens of garnet and olivine are different (see details in the text). Normalization is done relative to the composition of the undifferentiated mantle [Sun, McDonough, 1989]. The model of melting refers to the distribution coefficients from the articles mentioned in Fig. 11. Data of Zhi et al. [1990] and authors. 


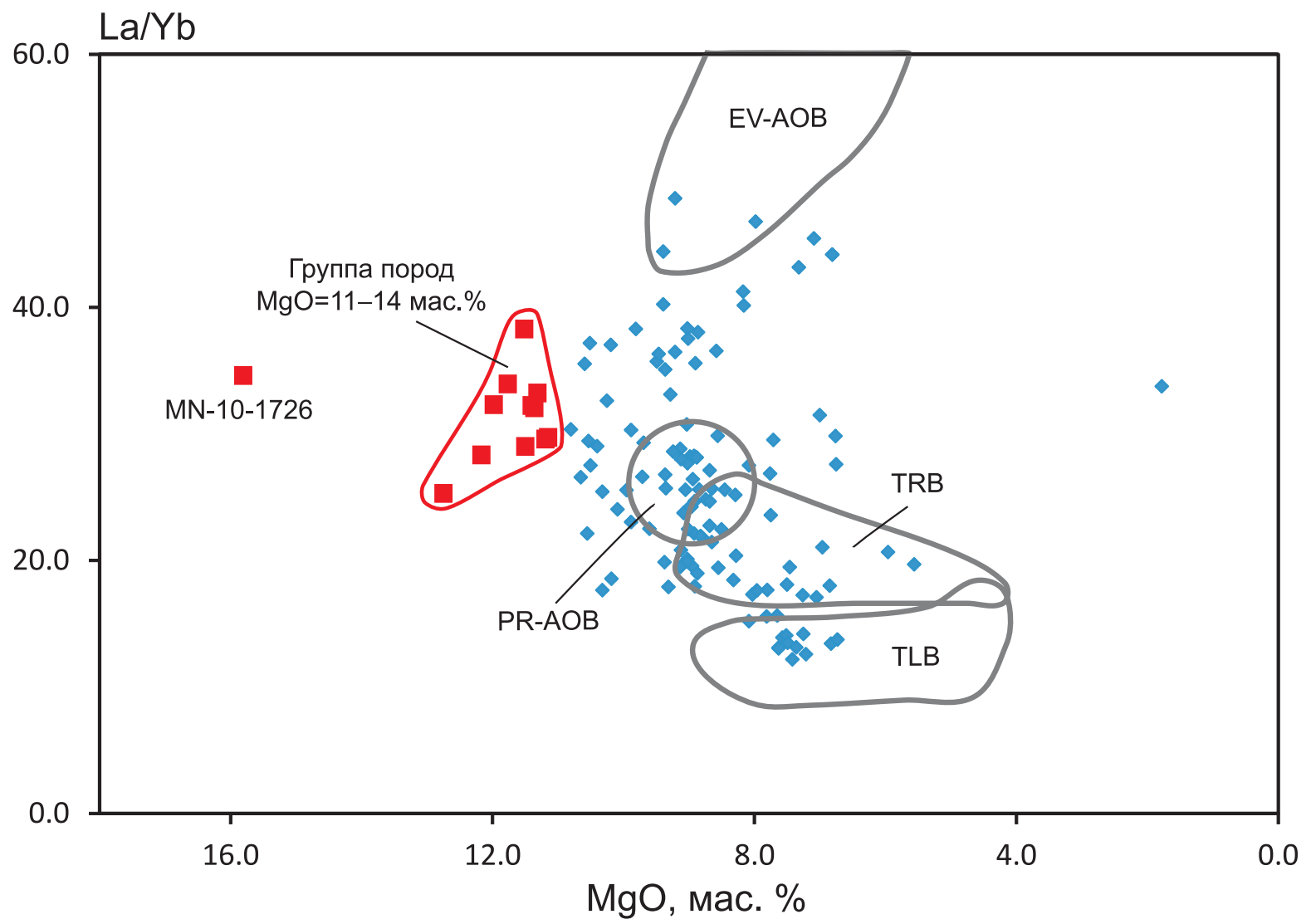

Рис. 13. Соотношения высокомагнезиальной и умеренномагнезиальной групп пород Дариганского поля на диаграмме La/Yb - MgO. Усл. обозн. см. рис. 3. Для сравнения нанесены фигуративные поля вулканических пород Ханнуобы: щелочные оливиновые базальты эволюционированные (EV-AOB) и примитивные (PR-AOB), переходные базальты (TRB) и толеитовые базальты (TLB).

Fig. 13. $\mathrm{La} / \mathrm{Yb}$ vs. MgO of high- and moderate-Mg groups of rocks from the Dariganga field. See the legend in Fig. 3. Figurative fields of the volcanic rock from the Hannuoba field, including evolved (EV-AOB) and primitive (PR-AOB) alkali olivine basalts, transitional basalts (TRB) and tholeiitic basalts (TLB), are shown for comparison.

Ханнуобы (рис. 13).

Из приведенных данных следует, что магматические процессы Ханнуобы и Дариганги в целом имели единую природу. Отличие заключалось в том, что на первой территории была представлена контрастная ассоциация лав (группа EV-AOB и группы PR-AOB, TRB, TLB), на второй - недостающее звено, т.е. промежуточная непрерывная серия, объединившая контрастные члены ассоциации между собой. Высокомагнезиальные лавы поля Дариганга выступают в контексте общей модели как дополнение к промежуточному угловому тренду умеренномагнезиальных лав.

\section{4. ОБОБЩЕННАЯ ПЕТРОГЕНЕТИЧЕСКАЯ МОДЕЛЬ}

Итак, мы принимаем гипотезу, согласно которой группы щелочных и переходных базальтов Ханнуобы были производными смешения астеносферного изотопно-обогащенного и глубинного изотопно-обедненного компонентов, а группа толеитовых базальтов производной смешения того же астеносферного компонента с материалом литосферы. В случае Дариганги нужно признать, с одной стороны, постепенный переход между подлитосферным и литосферным материалом и, с другой - действие дополнительного фактора, обеспечившего проникновение на земную поверхность из области магмообразования высокомагнезиальных (высокотемпературных) расплавов.

Согласованность геохимических данных по источникам вулканических пород полей Ханнуоба и Дариганга, подчеркивающая в то же время своеобразие обстановок глубинных процессов, дает возможность развить обобщенную петрогенетическую модель процессов, протекавших над осевой частью ВосточноМонгольской низкоскоростной аномалии (рис. 14).

Контраст ассоциации пород Ханнуобы обусловлен пространственной обособленностью подлитосферных источников от источников основания литосферы, т.е. зарождением магм на двух глубинных уровнях. Активное адиабатическое поднятие материала сопровождалось его частичным декомпрессионным плавлением существенно ниже подошвы литосферы с вовлечением в плавление материала окружающей малоглубинной астеносферной мантии. Созданная благодаря этому 
a
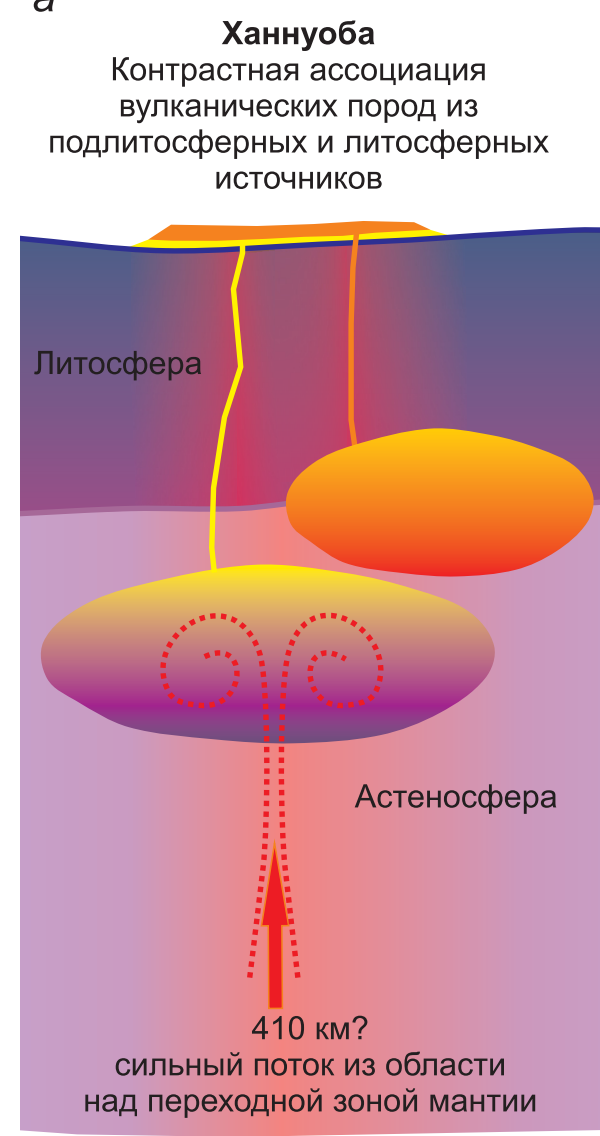

1

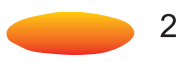

2

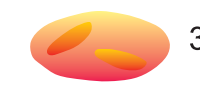

$\sigma$
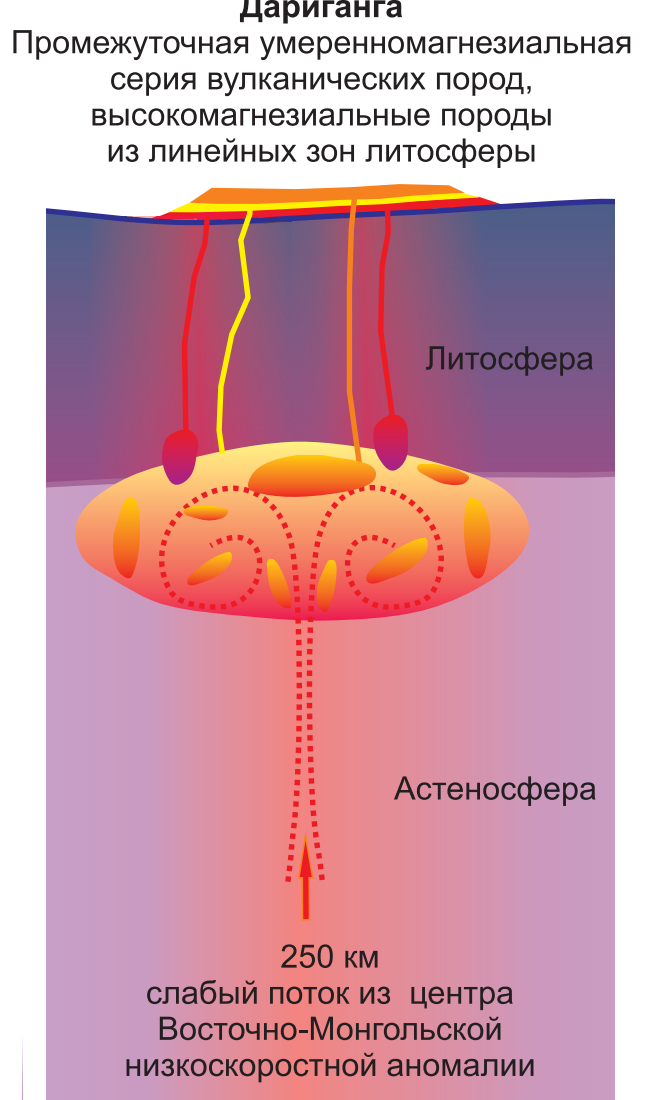

3

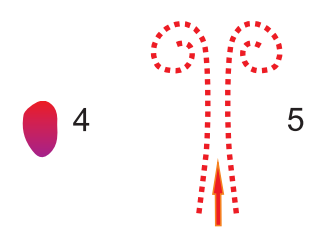

Рис. 14. Схемы магмообразования под вулканическими полями Ханнуоба (a) и Дариганга (б). 1 - магматический источник смеси изотопно-обогащенного астеносферного материала, подстилающего подошву литосферы, и более глубинного изотопно-обедненного материала; 2 - магматический источник смеси такого же астеносферного материала с материалом литосферы; 3 - перемешанный литосферный и подлитосферный материал промежуточного (умеренномагнезиального) состава; 4 - высокомагнезиальные выплавки в линейных зонах литосферы; 5 - восходящий мантийный поток.

Fig. 14. Schemes of magma formation under the Hannuoba (a) and Dariganga (б) volcanic fields. 1 - magmatic source of the mixture of the isotopically-enriched asthenospheric material, that is underlying the foot of the lithosphere, and the isotopically-depleted material from dipper levels; 2 - magmatic source of the mixture containing the same asthenospheric material and the lithospheric one; 3 - mixture of the sub-lithospheric and lithospheric materials of the intermediate (moderate-Mg) composition; 4 - high-Mg liquids in linear zones of the lithosphere; 5 - ascending mantle flow.

процессу плавучесть частично расплавленного материала превышала плавучесть кристаллических фаз вмещающей астеносферной мантии. В результате расплав высвобождался из матрицы, мигрировал вверх и изливался на земной поверхности. Привнос тепла способствовал концентрации процессов плавления на подошве литосферы. Образовавшиеся расплавы также оказывались достаточно плавучими, чтобы мигрировать из области магмообразования с излиянием на земной поверхности.

Непрерывность умеренномагнезиальной серии поля Дариганга отражает пространственное единство маг- мообразующих процессов. Узкий интервал содержаний граната в источниках расплавов этого поля, по результатам микроэлементного моделирования (см. рис. 12 , б), свидетельствует о вовлечении в однородное плавление материала восходящего мантийного потока с глубин, сопоставимых с минимальными глубинами магмообразования Ханнуобы у подошвы литосферы. Малая глубина выплавок явилась следствием более слабого (с меньшим теплосодержанием, чем под полем Ханнуоба) глубинного мантийного потока, изначально поднимавшегося под полем Дариганга. Для того чтобы началось декомпрессионное плавление в ослабленном 
восходящем потоке, он должен был достигнуть подошвы литосферы, инициируя плавление непосредственно в соприкосновении с ней. Образовавшийся ряд частичных выплавок с высокой плавучестью отделялся от области магмообразования в сочетании с высокомагнезиальными (высокотемпературными) расплавами, которые концентрировались вдоль линейных зон растяжения литосферы.

В связи с использованием в обобщенной модели магмообразования понятий «сильного» и «слабого» мантийных потоков заслуживает внимания гипотеза плавления верхней мантии, в которой предполагается особая роль переходной зоны. Постулируется зарождение выплавок в результате апвеллинга материала с глубины 410 км при содержании воды в переходной зоне более $\sim 0.05 \%$ [Hirschmann et al., 2009; Karato, 2012]. Такой материал должен находиться в частично расплавленном состоянии до тех пор, пока не достигнет основания литосферы. Эта модель может обсуждаться на материале Восточной Азии и, возможно, подобных этой территории континентальных окраин. Данные о наличии современного плавления на глубине около 410 км были получены при сейсмологических исследованиях и исследованиях электропроводности [Tauzin et al., 2010; Karato, 2011], которые выявили низкоскоростные области непосредственно выше 410 км. Тенденция распространения низкоскоростных аномалий над переходной зоной мантии была в целом характерна для всей территории Восточной Азии [Rasskazov et al., 2003].

Вулканическое поле Дариганга соответствует центральной части Восточно-Монгольской низкоскоростной аномалии, а поле Ханнуоба - ее юго-юго-западному окончанию (см. рис. 11). Сильный мантийный поток под полем Ханнуоба может рассматриваться как первичное выражение апвеллинга материала с глубинного уровня $\sim 410$ км. Ослабленный мантийный поток под полем Дариганга может интерпретироваться как отражение мантийного потока, начинающегося от низкоскоростной аномалии 250 км, образовавшейся по механизму остаточного утолщения мантийного потока вследствие ослабления глубинной термальной подпитки [Kumagai et al., 2007].

\section{7. ЗАКЛЮЧЕНИЕ}

На вулканическом поле Дариганга изучены соотношения химического состава высокомагнезиальных $(\mathrm{MgO}=11.0-15.8$ мас. \%) и умеренномагнезиальных $(\mathrm{MgO}=3.0-11.0$ мас. \%) вулканических пород. Установлен пространственный контроль вулканов с извержениями высокомагнезиальных лав линейными зонами протяженностью 90 км и более. При сравнительном анализе геохимических данных по породам вулканических полей Дариганга и Ханнуоба обоснованы петрогенетические модели однородного и контрастного мантийного магматизма. С учетом данных сейсмической томографии, модель магматизма первого типа может характеризовать обстановку процессов плавления, вызванных в источниках на границе астеносферы-литосферы и непосредственно нижележащей астеносферы сравнительно слабым мантийным потоком, возможно, поднимающимся с глубины 250 км. Модель магматизма второго типа предполагает инициирование процессов плавления в обособленных источниках подлитосферной мантии и границы астеносферы-литосферы изначально сильным мантийным потоком, возможно, зародившимся на глубине 410 км.

\section{8. БЛАГОДАРНОСТИ}

Работа выполнена по проекту ФЦП «Научные и научно-педагогические кадры инновационной России» на 2009-2013 годы», соглашение № 14.B37.21.1147.

\section{9. ЛИТЕРАТУРА}

Basu A.R., Junwen W., Wankang H., Guanghong X., Tatsumoto M., 1991. Major element, REE, and Pb, Nd and Sr isotopic geochemistry of Cenozoic volcanic rocks of Eastern China: implications for their origin from suboceanic-type mantle reservoirs. Earth and Planetary Science Letters 105 (1-3), 149-169. http://dx.doi.org/10.1016/0012-821X(91)90127-4.

Halliday A.N., Lee D.-C., Tommasini S., Davies G.R., Paslick C.R., Fitton J.G., James D.E., 1995. Incompatible trace elements in OIB and MORB and source enrichment in the sub-oceanic mantle. Earth and Planetary Science Letters 133 (3-4), 379-395. http://dx.doi.org/10.1016/0012-821X(95)00097-V.

Hart S.R., Dunn T., 1993. Experimental cpx/melt partitioning of 24 trace elements. Contributions to Mineralogy and Petrology 113 (1), 1-8. http://dx.doi.org/10.1007/BF00320827.

Hauri E.H., Wagner T.P., Grove T.L., 1994. Experimental and natural partitioning of Th, U, $\mathrm{Pb}$ and other trace elements between garnet, clinopyroxene and basaltic melts. Chemical Geology 117 (1-4), 149-166. http://dx.doi.org/10.1016/00092541(94)90126-0.

Herzberg C., 2011. Identification of source lithology in the Hawaiian and Canary islands: implications for origins. Journal of Petrology 52 (1), 113-146. http://dx.doi.org/10.1093/petrology/egq075.

Hirschmann M.M., Tenner T., Aubaud C., Withers A.C., 2009. Dehydration melting of nominally anhydrous mantle: the primacy of partitioning. Physics of the Earth and Planetary Interiors 176 (1-2), 54-68. http://dx.doi.org/10.1016/j.pepi. 2009.04.001. 
Ionov D.A., Griffin W.L., O'Reilly S.Y. , 1997. Volatile-bearing minerals and lithophile trace elements in the upper mantle. Chemical Geology 141 (3-4), 153-184. http://dx.doi.org/10.1016/S0009-2541(97)00061-2.

Karato S-I., 2011. Water distribution across themantle transition zone and its implications for global material circulation. Earth and Planetary Science Letters 301 (3-4), 413-423. http://dx.doi.org/10.1016/j.epsl.2010.11.038.

Karato S-I., 2012. On the origin of the asthenosphere. Earth and Planetary Science Letters 321-322, 95-103. http://dx.doi. org/10.1016/j.epsl.2012.01.001.

Kepezhinskas V.V., 1979. The Cenozoic Alkaline Basaltoids of Mongolia and Their Deep Inclusions. Nauka, Moscow, 311 p. (in Russian) [Кепежинскас В.В. Кайнозойские щелочные базальтоиды Монголии и их глубинные включения. М.: Наука, 1979. 311 с.].

Keshav S., Gudfinnsson G.H., Sen G., Fei Y.-W., 2004. High-pressure melting experiments on garnet clinopyroxenites and the alkalic to tholeiitic transition in ocean-island basalts. Earth and Planetary Science Letters 223 (3-4), 365-379. http://dx. doi.org/10.1016/j.epsl.2004.04.029.

Kononova V.A., Ivanenko V.V., Karpenko M.I., Arakelyants M.M.,Andreeva E.D.,Pervov V.A., 1988. New data on the K-Ar age of the Cenozoic continental basalts of the Baikal rift system. Doklady AN SSSR 303 (2), 454-457 (in Russian) [Koнонова В.А., Иваненко В.В., Карпенко М.И., Аракелянц М.М., Андреева Е.Д., Первов В.А. Новые данные о К-Ar возрасте кайнозойских континентальных базальтов Байкальской рифтовой системы // Доклады АН СССР. 1988. T. 303. № 2. C. 454-457].

Kumagai I., Davaille A., Kuruta K., 2007. Successful and failed plumes: the Icelandic case. Geophysical Research Abstracts 9, 04028.

Liu J., Han J., Fyfe W.S., 2001. Cenozoic episodic volcanism and continental rifting in Northeast China and possible link to Japan Sea development as revealed from K-Ar geochronology. Tectonophysics 339 (3-4), 385-401. http://dx.doi.org/10. 1016/S0040-1951(01)00132-9.

Lloyd F.E., Arima M., Edgar A.D., 1985. Partial melting of a phlogopite clinopyroxenite nodule from south-west Uganda: an experimental study bearing on the origin of highly potassic continental rift volcanics. Contributions to Mineralogy and Petrology 91 (4), 321-329. http://dx.doi.org/10.1007/BF00374688.

Pertermann M., Hirschmann M.M., 2003. Anhydrous partial melting experiments on MORB-like eclogite: phase relations, phase compositions and mineral-melt partitioning of major elements at 2-3 GPa. Journal of Petrology 44 (12), 21732201.

Rasskazov S.V., 1985. The Udokan Basaltoids. Nauka, Siberian Branch, Novosibirsk, 142 p. (in Russian) [Рассказов C.В. Базальтоиды Удокана. Новосибирск: Наука. Сибирское отделение, 1985. 142 с.].

Rasskazov S.V., 1987. Deep inclusions of the Late Cenozoic melanephelinites of the Southern Central Transbaikalia. Geology and Geophysics 7, 50-60 (in Russian) [Рассказов С.В. Глубинные включения из позднекайнозойских меланефелинитов юга Центрального Забайкалья // Геология и геофизика. 1987. № 7. С. 50-60].

Rasskazov S.V., 1993. Magmatism of the Baikal Rift System. VO Nauka, Siberian Publishing House, Novosibirsk, 288 p. (in Russian) [Рассказов С.В. Магматизм Байкальской рифтовой системы. Новосибирск: ВО Наука. Сибирская издательская фирма, 1993. 288 с.].

Rasskazov S.V., Boven A., Andre L., Liegeois J.-P., Ivanov A.V., Punzalan L., 1997. Evolution of magmatism in the Northeastern Baikal rift system. Petrology 5 (2), 101-120.

Rasskazov S.V., Brandt S.B., Brandt I.S., 2010. Radiogenic isotopes in geologic processes. Springer, New York, 306 p.

Rasskazov S.V., Chuvashova I.S., Liu J., Meng F., Yasnygina T.A., Fefelov N.N., Saranina E.V., 2011. Proportions of lithospheric and asthenospheric components in Late Cenozoic K and K-Na lavas in Heilongjiang Province, Northeastern China. Petrology 19 (6), 568-600. http://dx.doi.org/10.1134/S0869591111050031.

Rasskazov S.V., Chuvashova I.S., Yasnygina T.A., Fefelov N.N., Saranina E.V., 2012. Potassium and Potassium-Soda Volcanic Series in the Cenozoic Asia. GEO Academic Publishing House, Novosibirsk, 310 p. (in Russian) [Рассказов С.В., Чувашова И.С., Ясныгина Т.А., Фефелов Н.Н., Саранина Е.В. Калиевая и калинатровая вулканические серии в кайнозое Азии. Новосибирск: Академическое издательство «ГЕО», 2012. 310 с.].

Rasskazov S.V., Logachev N.A., Kozhevnikov V.M., Yanovskaya T.B., 2003. Multistage Dynamics of the Upper Mantle in Eastern Asia: Relationships between Wandering Volcanism and Low-Velocity Anomalies. Doklady Earth Sciences 390 (4), 492-496.

Sakhno V.G., Maksimov S.O., Popov V.K., Sandimirova G.P., 2004. Leucite basanites and potassium shonkinites of the Uglovoe Basin, Southern Primorye. Doklady Earth Sciences 399 (9), 1322-1327.

Saltykovsky A.Ya., Genshaft Yu.S., 1985. Geodynamics of the Cenozoic Volcanism in the South-Eastern Mongolia. Nauka, Moscow, 135 p. (in Russian) [Салтыковский А.Я., Геншафт Ю.С. Геодинамика кайнозойского вулканизма юговостока Монголии. М.: Наука, 1985. 135 с.]

Şengör A.M., Natal'in B.A., 1996. Paleotectonics of Asia: fragments of a synthesis. In: A. Yin, M. Harrison (Eds.), The tectonic evolution of Asia. V. 21. Cambridge University Press, Cambridge, p. 486-640.

Sobolev A.V., Hofmann A.W., Kuzmin D.V., Yaxley G.M., Arndt N.T., Chung S.-L., Danyushevsky L.D., Elliott T., Frey F.A., Garcia M.O., Gurenko A.A., Kamenetsky V.S., Kerr A.C., Krivolutskaya N.A., Matvienkov V.V., Nikogosian I.K., 
Rocholl A., Sigurdsson I.A., Sushchevskaya N.M., Teklay M., 2007. The amount of recycled crust in sources of mantlederived melts. Science 316 (5823), 412-417. http://dx.doi.org/10.1126/science. 1138113.

Sobolev A.V., Hofmann A.W., Sobolev S.V., Nikogosian I.K., 2005. An olivine-free mantle source of Hawaiian shield basalts. Nature 430 (7033), 590-597. http://dx.doi.org/10.1038/nature03411.

Song Y., Frey F.A., Zhi H., 1990. Isotopic characteristics of Hannuoba basalts, eastern China: implications for their petrogenesis and the composition of subcontinental mantle. Chemical Geology 88 (1-2), 35-52. http://dx.doi.org/10.1016/ 0009-2541(90)90102-D.

Sun S.-S., McDonough W.F., 1989. Chemical and isotopic systematics of oceanic basalts: implications for mantle composition and processes. In: A.D. Sounders, M.J. Norry (Eds.), Magmatism in the ocean basins. Geological Society Special Publication, V. 42, p. 313-345. http://dx.doi.org/10.1144/GSL.SP.1989.042.01.19.

Syrnev I.P., 1982. East Mongolian Plain. In: Geomorphology of the Mongolian People's Republic. The Joint SovietMongolian Research Expedition. Proceedings, Issue 28. Nauka, Moscow, p. 166-176 (in Russian) [Сырнев И.П. Восточно-Монгольская равнина // Геоморфология Монгольской Народной Республики. Совместная Советско-Монгольская научно-исследовательская экспедиция. Труды, Вып. 28. М.: Наука, 1982. С. 166-176].

Tatsumoto M., Basu A.R., Wankang H., Junwen W., Guanghong X., 1992. Sr, Nd, and Pb isotopes of ultramafic xenoliths in volcanic rocks of East China: enriched components EMI and EMII in subcontinental lithosphere. Earth and Planetary Science Letters 113 (1-2), 107-128. http://dx.doi.org/10.1016/0012-821X(92)90214-G.

Tauzin B., Debayle E., Wittingger G., 2010. Seismic evidence for a global low-velocity layer within the Earth's upper mantle. Nature Geoscience 3 (10), 718-721. http://dx.doi.org/10.1038/ngeo969.

Vlodavets V.I., 1955. About some features of the Cenozoic volcanism of the Darigang region in Mongolia. In: Problems of Geology of Asia. Publishing House of the USSR Academy of Sciences, Moscow, V. 2. p. 679-685 (in Russian) [Влодавец В.И. О некоторых чертах кайнозойского вулканизма Даригангской области Монголии // Вопросы геологии Азии. М.: Издательство АН СССР, 1955. Т. 2. С. 679-685].

Yanovskaya T.B., Kozhevnikov V.M., 2003. 3D S-wave velocity pattern in the upper mantle beneath the continent of Asia from Rayleigh wave data. Physics of the Earth and Planetary Interiors 138 (3-4), 263-278. http://dx.doi.org/10.1016/ S0031-9201(03)00154-7.

Yasnygina T.A., Rasskazov S.V., Markova M.E., Ivanov A.V., Demonterova E.I., 2003. Determination of trace elements by ICP-MS method with application of microwave acid decomposition in volcanic rocks of basic and intermediate composition. In: Applied Geochemistry. Issue 4. Analytical Studies. IMGRE, Moscow, p. 48-56 (in Russian) [Ясныгина T.A., Рассказов С.В., Маркова М.Е., Иванов А.В., Демонтерова Е.И. Определение микроэлементов методом ICP-MS с применением микроволнового кислотного разложения в вулканических породах основного и среднего состава // Прикладная геохимия. Вып. 4. Аналитические исследования. М.: ИМГРЭ, 2003. С. 48-56].

Zhang M., Suddaby P., Thompson R.N., Thirlwall M.F., Menzies M.A., 1995. Potassic rocks in NE China: geochemical constraints on mantle source and magma genesis. Journal of Petrology 36 (5), 1275-1303. http://dx.doi.org/10.1093/ petrology/36.5.1393.

Zhi X., Song Y., Frey F.A., Feng J., Zhai M., 1990. Geochemistry of Hannuoba basalts, Eastern China: constraints on the origin of continental alkalic and tholeiitic basalt. Chemical Geology 88 (1-2), 1-33. http://dx.doi.org/10.1016/0009-2541(90) 90101-C.

Zhou X.-H., Zhu B.-Q., Liu R.-X., Chen W-J., 1988. Cenozoic basaltic rocks in Eastern China. In: Continental flood basalts. Kluwer Academic Publishers, p. 311-330.

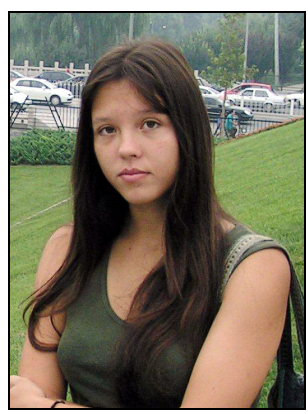

Чувашова Ирина Сергеевна, канд. геол.-мин. наук, н.с.

Институт земной коры СО РАН

664033, Иркутск, ул. Лермонтова, 128, Россия

Тел.+7(3952)511659; $₫$ e-mail: chuvashova@crust.irk.ru

Иркутский государственный университет, геологический факультет, старший преподаватель

кафедры динамической геологии

Chuvashova, Irina S., Candidate of Geology and Mineralogy, Researcher

Institute of the Earth's Crust, Siberian Branch of RAS

128 Lermontov street, Irkutsk 664033, Russia

Tel.+7(3952)511659; $\bowtie$ e-mail: chuvashova@crust.irk.ru

Senior Lecturer of Dynamic Geology Chair, Irkutsk State University, Geological Faculty 


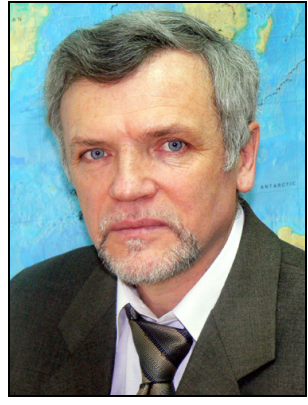

Рассказов Сергей Васильевич, докт. геол.-мин. наук, профессор, зав. лабораторией Институт земной коры СО РАН

664033, Иркутск, ул. Лермонтова, 128, Россия

Тел. (3952)511659; $₫$ e-mail: rassk@crust.irk.ru

Иркутский государственный университет, геологический факультет, зав. кафедрой динамической геологии

Rasskazov, Sergey V., Doctor of Geology and Mineralogy, Professor, Head of Laboratory Institute of the Earth's Crust, Siberian Branch of RAS

128 Lermontov street, Irkutsk 664033, Russia

Tel.+7(3952)511659; e-mail: rassk@crust.irk.ru

Head of Dynamic Geology Chair, Irkutsk State University, Geological Faculty

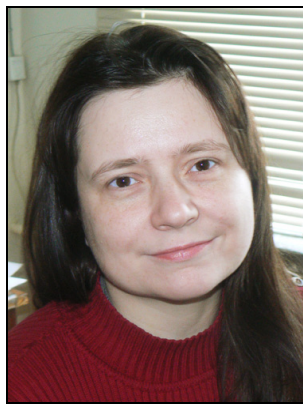

Ясныгина Татьяна Александровна, канд. геол.-мин. наук, с.н.с.

Институт земной коры СО РАН

664033, Иркутск, ул. Лермонтова, 128, Россия

Тел. 8(3952)511659; e-mail: ty@crust.irk.ru

Yasnygina, Tatiana A., Candidate of Geology and Mineralogy, Senior Researcher

Institute of the Earth's Crust, Siberian Branch of RAS

128 Lermontov street, Irkutsk 664033, Russia

Tel.8(3952)511659; e-mail: ty@crust.irk.ru

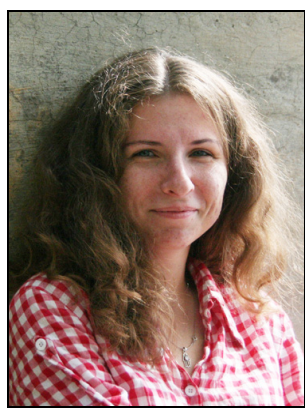

Михеева Екатерина Андреевна, старший лаборант

Институт земной коры СО РАН

664033, Иркутск, ул. Лермонтова, 128, Россия

Тел. +7(3952)511659

Иркутский государственный университет, геологический факультет, магистрант

Mikheeva, Ekaterina A., Senior Lab Assistant

Institute of the Earth's Crust, Siberian Branch of RAS

128 Lermontov street, Irkutsk 664033, Russia

Tel. +7(3952)511659

Candidate for Master Degree, Irkutsk State University, Geological Faculty 